Received: 03 Aug. 2021/Approved: 08 Nov. 2021

\title{
FUTURE RESEARCH GUIDELINES ON SOFT POWER: AN OBLIQUE APPROACH OF THE LITERATURE ON THE INTERTWINEMENT BETWEEN CREATIVE INDUSTRIES AND PLACE BRANDING
}

\author{
Rodolfo Paião de Campos \\ School of Economics, Business Administration and Accounting at Ribeirão Preto - University of São Paulo \\ (FEA-RP/USP) \\ Ribeirão Preto, São Paulo - Brazil. \\ rodolfo.decampos@usp.br \\ Simone Vasconcelos Ribeiro Galina \\ School of Economics, Business Administration and Accounting at Ribeirão Preto - University of São Paulo \\ (FEA-RP/USP) \\ Ribeirão Preto, São Paulo - Brazil. \\ svgalina@usp.br \\ Janaina de Moura Engracia Giraldi \\ School of Economics, Business Administration and Accounting at Ribeirão Preto - University of São Paulo \\ (FEA-RP/USP) \\ Ribeirão Preto, São Paulo - Brazil. \\ jgiraldi@usp.br
}

Objective: The objective of this paper is to present cross-disciplinary future research guidelines on soft power, analyzing its intertwinement with creative industries and place branding.

Methodology: A systematic literature review is performed using Methodi Ordinatio in Scopus database. Papers are ranked according to their relevance and reviewed using content analysis techniques and oblique approach.

Main results: Although several authors do not make use of the term soft power itself, most of them obliquely allude to its concept, from where we draw inferences for future research.

Contributions: Through Methodi Ordinatio, we identified the most relevant articles on the object of study. Analyzing them, our main contribution is an array of guidelines for future research on soft power in six areas: psychosociology, labor mobility, urban planning, arts diplomacy, gastrodiplomacy, and geographical indications.

Relevance and originality: to our knowledge, the triangle of creative industries, place branding, and soft power has been studied only to a very limited extent, and this seems to be the first article to link it to the aforementioned areas.

Managerial and social implications: Not only does this triangle contain uncharted theoretical challenges, but it also puts forward underexplored areas by practitioners and policy-makers, provoking insights for the image planning of cities, regions, and countries. The need for further studies notwithstanding, the areas involving arts and gastronomy seem to be feasible initiatives for the short-term, meanwhile the other ones may be more time and cost consuming.

Keywords: Soft power. Place branding. Creative industry. Creative economy. Methodi Ordinatio.

\section{How to cite the article}

American Psychological Association (APA)

Campos, R. P., Galina, S. V. R., \& Giraldi, J. de. M. E. (2022, Jan./Mar.). Future research guidelines on soft power: an oblique approach of the literature on the intertwinement between creative industries and place branding. Brazilian Journal of Marketing, 21(Special Issues), 109-134. https://doi.org/10.5585/remark.v21i1.20541. 


\section{Introduction}

One of the most renowned scientists in history was consumed by a unique sentiment. Germans call it Fernweh. Even at young age, Alexander von Humboldt always "felt and inexplicable pull towards the unknown" (Wulf, 2015, p. 34) perhaps due to the fact that, as a boy, he "had read the journals of Captain James Cook and Louis Antoine de Bougainville, both of whom had circumnavigated the globe, and imagined himself far away." (Wulf, 2015, p. 32).

Built on the words far (fern) and painful (weh), the term denotatively describes a longing or ache to travel to other countries (Cambridge Dicionary, 2018). Despite its puzzling etymology, the word is somewhat a popular way to refer to a person who is homesick for a place they have never been to.

One may agree that this signification is intriguing. In any case, this study is not an attempt to explore this unusual word. This prologue about Humboldt's life, however, highlights how creative goods may engender attraction to different places throughout the world.

Scientifically, there are basically two branches of knowledge concerning the image and attraction of places. Soft power is a political term to elucidate the ability that some nations have to shape and move people - not through threats, coercion, or payments - but engaging the international audience with the image of their culture, political ideals, and policies (Nye, 2004). In parallel, marketing scholars have also been trying to understand how images of places are shaped in people's minds and how they alter their behavior towards these places, classifying this area as nation branding, place branding, or place marketing.

Put it briefly, soft power and place branding are intertwined, and not only with themselves, but also with the theories and practices of creative industries - such as the books Humboldt have read - for they globally create images of places in people' minds. In soft power research, this image acts as an illustration of the economic, technological, political, and social development of a place. As for nation branding, it portrays its products, innovation, status, reliability, and labor (Anholt, 2005; Maheshwari et al., 2019; Valaskivi, 2013).

On one hand, it is known that "soft power and nation branding are in a direct relationship with each other" (Kahraman, 2016, p. 95), where, "nation branding initiatives can serve as steps towards acquiring soft power by increasing the awareness of international audiences pertaining to the unique elements of a nation" (Rookwood, 2019, p. 31). On the other, however, there are numerous publications where these concepts are still confusingly and ambiguously employed (Boisen et al., 2017; Fan, 2010; Hao et al., 2019; Skinner, 2008). 
We posit that this unintentional cross-disciplinarity may lead to unexplored paths on these different (yet complementary) areas of knowledge. So, the central purpose of this work is to explore this conceptual entanglement as a means of developing guidelines for future research.

To do so, we present a systematic literature review and content analysis of 39 texts published on Scopus-indexed journals. We first used Methodi Ordinatio (Pagani et al., 2015) to find, select, and rank the publications using a set of several related keywords.

Then, we scanned the frequency of occurrence of the keyword ["soft power"], using the software VOSviewer, in all texts to verify whether the authors had made direct use of the term.

Considering that most of them had not, we analyzed the content of all texts to find out whether they obliquely refer to soft power - according to Kay (2011), obliquity is the process of achieving complex objectives indirectly. In other words, we use the oblique approach to verify whether authors on place branding might have been indirectly alluding to soft power, which allowed us to find out is that most authors have. Additionally, from the results we observed that their oblique references contain peculiar insights for future research in six different areas: psychosociology, labor mobility, urban planning, arts diplomacy, gastrodiplomacy, and geographical indications.

As a final contribution, we conjecture and present two additional paths for future research: the misguided interpretations of place branding, and the dynamics of access to place image through creative and traditional products, emphasizing counterfeit ones.

\section{Theoretical foundations}

The term soft power was coined by Harvard professor Joseph Nye Jr. in 1990 to explore the cultural, ideological, and attractive power of the United States during the Cold War period.

The ability to establish preferences tends to be associated with intangible power resources such as culture, ideology, and institutions. This dimension can be thought of as soft power, in contrast to the hard command power usually associated with tangible resources like military and economic strength. (Nye, 1990, p. 45)

Almost simultaneously, in 1996, the independent policy advisor Simon Anholt started writing about nation branding (Anholt, 2010). Although the author himself has coined the term, it is worth noting that he believes that "there is no such a thing as 'nation branding'. [...] The idea that it is possible to 'do branding' to a country (or to a city or region) in the same way that companies 'do branding' to their products, is both vain and foolish." (Anholt, 2010, p. 10) 
The brand of a nation and its soft power can then be understood as the total sum of its perceptions in the minds of international stakeholders, viz its people, place, culture and language, history, food, fashion, famous faces, global brands and so on (Fan, 2010). "Latin American telenovelas, Japanese comic books, Hong Kong kung fu movies, West African music, London fashions, Balinese tourist resorts, Australian wines, and Mexican cuisine" are examples of an ever-widening palette of cultural and creative products through which places are branded and can get internationally known and admired (Scott, 2004, p. 482).

In politics, the attractiveness of the brand of a nation is paramount. Popular cultural attraction contributed to the American victory in the Cold War, for example, seeing that "Soviet state-run propaganda and culture programs could not keep pace with the influence of America's commercial popular culture in flexibility or attraction." (Nye, 2004, p. 49)

So places want to appear in people's minds innovative, creative, interesting, authentic, and alluring (Valaskivi, 2013), be it for political or economic reasons. But, bearing in mind that people usually lack direct experiences in other countries, perceptions about different nations are mostly shaped by feelings and habits rather than information and knowledge (Wang, 2013).

And this is why creative and cultural products are one of the bridges between people and places. As Nye says, "much of American soft power has been produced by Hollywood, Harvard, Microsoft, and Michael Jordan" (2004, p. 17). And, nowadays, in a time when the images of a country can be more easily and creatively broadcasted worldwide, the race for soft power is tougher than ever, and traditional 'powers', such as the United States and France, have to compete with 'newcomers', such as China, India, and Brazil (Marc, 2019).

For Anholt (2010), place/nation branding is not about communications, but about policies - as soft power. In fact, nation branding is a communication arm of public diplomacy for building soft power. The difference is that whereas studies on diplomacy and soft power commonly emphasize politics, nation branding focus on economic change (Johnson, 2018).

De facto, social, political, and methodological challenges overlap when it comes to place branding (Florek et al., 2021) and "the way in which countries and regions understand and manage their external reputation and internal purpose" (Anholt, 2010, p. 111).

For one thing, the application of branding for places is of great political interest (Mariutti $\&$ Giraldi, 2021). The consumption of cultural and creative goods can associate consumers with a particular social identity, and, at a particular point, with a precise political tendency (Navarro, 2016), ultimately increasing or decreasing this place's attractiveness and soft power. Moreover, administrative policymaking is also fundamental to place branding, where the continuous and 
efficient participation of governmental institutions are entirely necessary. As a matter of fact, "as a publicly-funded and managed activity, place branding requires legitimacy which can only be achieved if its outcomes and impacts are recognized and understood by city managers, communities and other stakeholders" (Florek et al., 2021, p. 12)

This is why it is important to treat this phenomenon an interdisciplinary domain (Bell, 2016; Hankinson, 2010; Lucarelli \& Berg, 2011; Mariutti \& Tench, 2016), involving different parts of society in practice and different parts of knowledge in theoretical approaches.

Scientifically, the conceptual overlap between place branding and soft power encompasses more than foreign and domestic policy - one of the vertices of the National Brand Hexagon (Anholt, 2005), and also used by Nye in soft power). Both areas also refer to culture.

Numerous scholars understand place brands as complex cultural phenomena (Lucarelli \& Giovanardi, 2016), constituted by their interplay with identity and image (Pedeliento \& Kavaratzis, 2019). As to soft power and "according to the theories of international relations and international diplomacy, the experiences of individuals with cultural products and services may be seen as a form of ideological and cultural influence" (Rabêlo Neto et al., 2021, p. 2).

A voluminous literature notwithstanding, much remains to be understood about soft power and nation branding simply because attraction is a subjective experience (Mattern, 2005), many times created by creative/cultural industries. As far as we are concerned, this triangle of creative industries, place branding, and soft power has been studied only to a very limited extent.

Lee (2021), for instance, examines the nation branding of South Korea at the Oscarwinning movie Parasite, from 2019, and how it may have enhanced the country's soft power and cultural diplomacy. Marc (2019) narrates how French culture and popular music have been used to convey a new image of France, shifting from a focus on elite culture towards an economic, neoliberal approach, to gain international influence. Fung (2016) explores how China implemented a cultural policy of nation branding - both domestically and internationally - as a way of boosting its national industries of music, film, animation, and online games.

All in all, it seems that the attractiveness of creative industries can be directly or obliquely connected to the concepts of place branding and soft power, even partially. Culture and creativity are not only core values of place brands (Dudek-Mańkowska \& Grochowski, 2019, p. 276), but also be an essential political tool for successful power (Galeeva, 2020). 


\section{Methodology}

\subsection{Selection and ranking of publications using Methodi Ordinatio}

Methodi Ordinatio is a 9-step methodology (Figure 1) proposed by Pagani et al. (2015) for searching, selecting, and organizing relevant scientific studies, based on three criteria: impact factor, year of publication and number of citations.

\section{Figure 1}

Methodi Ordinatio

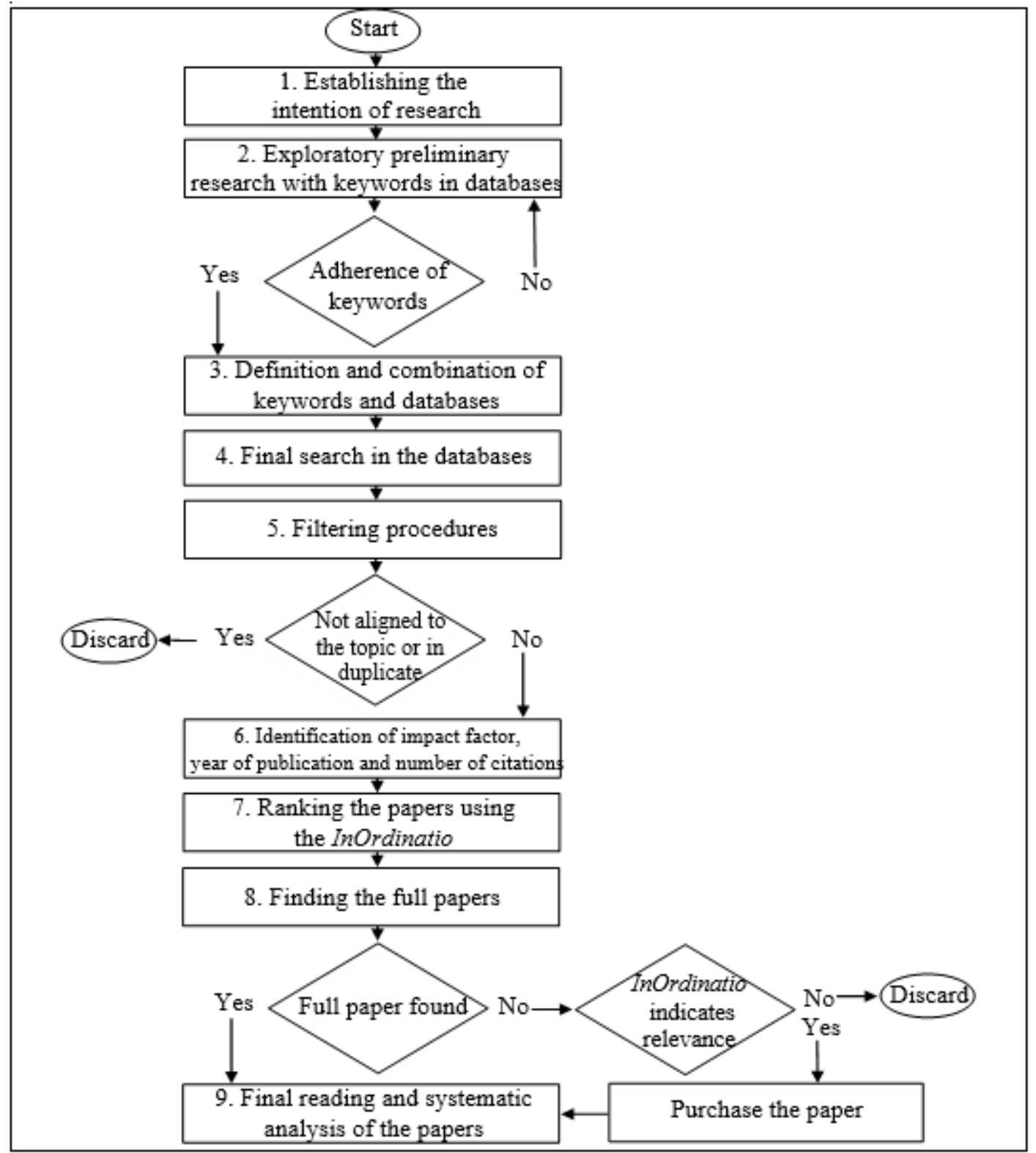

Source: Pagani et al. (2015, p. 2122). 
Phase 1 -Establishing the intention of research: The objective of this research is to present future research guidelines on soft power analyzing its intertwinement with two branches of knowledge: creative industries and place branding. Our intention is to explore this conceptual overlap in relevant studies as a means of finding new, cross-disciplinary paths.

Phase 2 - Preliminary research with keywords: Elsevier's Scopus well-known scientific database is used for it contains a comprehensive overview of the world's research production. We have first selected ["place branding"], ["creative economy"] as opening query strings. The TITLE-ABS-KEY default search field was used.

Phase 3 - Final decision on keywords combinations and databases: The resulting studies on the previous phase were conducive to a wider and more robust set of keywords, as shown in Figure 2, representing the final set of keywords to explored.

Phase 4-Final search on databases using a reference manager: A total of 20 document searches were carried out with the keywords intertwined, as demonstrated in Figure 2. It resulted in 49 articles. Books and book chapters are impractical for the equation InOrdinatio considering that they do not have a measure of impact factor, and thus are not considered here.

\section{Figure 2}

Keywords related to creative industries and place branding

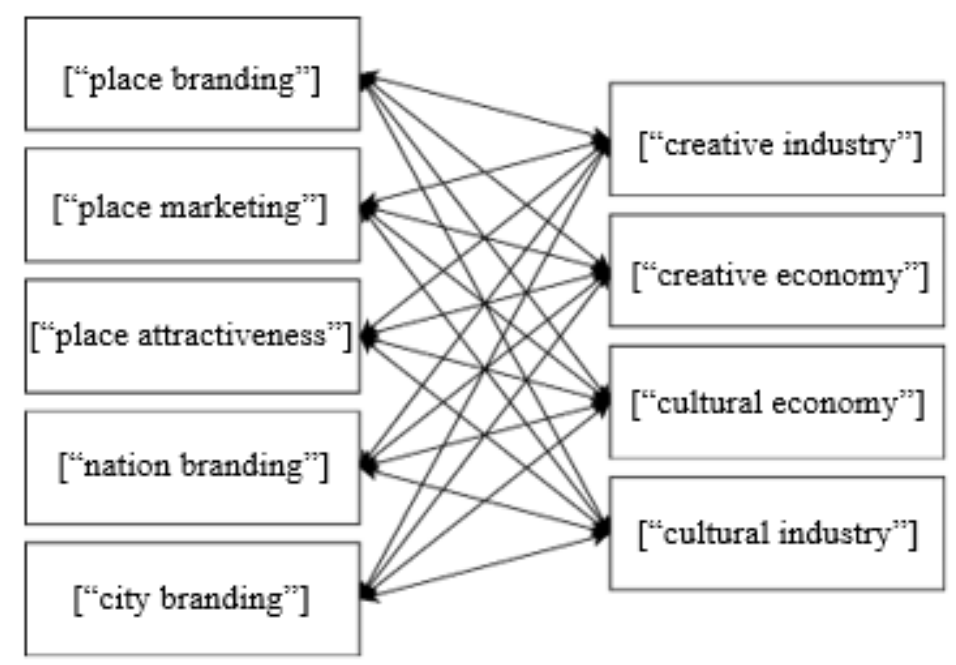

Source: Elaborated by the authors.

Phase 5 - Filtering procedures: The resulting articles were organized using reference managers, as recommended by the authors of Methodi Ordinatio. Mendeley is a free software and social network provided by academic publisher Elsevier, and JabRef is also an open- 
sourced platform used to collect, edit, organize, and cite academic work. We used Mendeley to export the papers from Scopus database, perform filtering procedures, and find duplicate works - from the first 49 papers, 10 were duplicates, resulting in 39 papers. JabRef was then used to organize the resulting articles more easily, in tables.

Phase 6 -Identification of impact factor, year of publication and number of citations: Year of publication is available for every paper after exporting them to the reference managers, but the impact factor of each publishing journal and the number of citations of each article had to be obtained from two other sources. The impact factor was retrieved from The SCImago Journal \& Country Rank, a publicly available portal for scientific indicators contained in Scopus database. The number of citations was collected from Google Scholar platform.

Phase 7 - Ranking the papers using the InOrdinatio: The equation InOrdinatio is applied to rank the papers according to their relevance: the higher the value obtained, the more relevant the paper. The resulting articles are ranked and presented in Table 1.

$$
\text { InOrdinatio }=\left(\frac{I F}{1000}\right)+\alpha *\left[10-(\text { ResearchYear }- \text { PublishYear }]+\left(\sum C i\right),\right. \text { where }
$$

- IF is the journal's impact factor (divided by 1000 for normalization).

- $\alpha$ is a weighting factor. It varies from 1 to 10 to represent the researcher's opinion on the relevance of the criterion year - considering that the earliest publication dates from 2004 , we have established the weighting factor $\alpha$ as 10 , as suggested by the authors for relatively new themes.

- $C i$ is the number of times the paper has been cited.

Table 1

Resulting Papers From Methodi Ordinatio

\begin{tabular}{|c|c|c|c|c|c|c|}
\hline No. & Authors & Title & InOrdinatio & Year & $\mathbf{F i}$ & $\mathbf{C i}$ \\
\hline 1 & Scott (2004) & $\begin{array}{l}\text { Cultural-products industries and urban } \\
\text { economic development: Prospects for growth } \\
\text { and market contestation in global context }\end{array}$ & 694,00 & 2004 & 1,189 & 754 \\
\hline 2 & $\begin{array}{l}\text { Currid \& Williams } \\
\text { (2010) }\end{array}$ & $\begin{array}{l}\text { The geography of buzz: Art, culture and the } \\
\text { social milieu in Los Angeles and New York }\end{array}$ & 178,00 & 2010 & 2,192 & 178 \\
\hline 3 & Lee et al. (2015) & $\begin{array}{l}\text { Creative food clusters and rural development } \\
\text { through place branding: Culinary tourism } \\
\text { initiatives in Stratford and Muskoka, Ontario, } \\
\text { Canada }\end{array}$ & 144,00 & 2015 & 1,624 & 94 \\
\hline 4 & Valaskivi (2013) & $\begin{array}{l}\text { A brand new future? Cool Japan and the } \\
\text { social imaginary of the branded nation }\end{array}$ & 131,00 & 2013 & 0,259 & 101 \\
\hline
\end{tabular}




\begin{tabular}{|c|c|c|c|c|c|c|}
\hline No. & Authors & Title & InOrdinatio & Year & $\mathbf{F i}$ & $\mathbf{C i}$ \\
\hline 5 & Jones (2009) & $\begin{array}{l}\text { Putting architecture in its social place: A } \\
\text { cultural political economy of architecture }\end{array}$ & 117,00 & 2009 & 1,618 & 127 \\
\hline 6 & Lange et al. (2008) & $\begin{array}{l}\text { Berlin's creative industries: Governing } \\
\text { creativity? }\end{array}$ & 107,00 & 2008 & 1,738 & 127 \\
\hline 7 & $\begin{array}{l}\text { Ulldemolins \& } \\
\text { Zamorano (2015) }\end{array}$ & $\begin{array}{l}\text { Spain's nation branding project Marca España } \\
\text { and its cultural policy: the economic and } \\
\text { political instrumentalization of a } \\
\text { homogeneous and simplified cultural image }\end{array}$ & 104,00 & 2015 & 0,607 & 54 \\
\hline 8 & Cudny et al. (2020) & $\begin{array}{l}\text { Arts and creativity: A business and branding } \\
\text { strategy for Lodz as a neoliberal city }\end{array}$ & 102,00 & 2020 & 1,606 & 2 \\
\hline 9 & Oh (2020) & $\begin{array}{l}\text { From concrete walls to digital walls: } \\
\text { transmedia construction of place myth in } \\
\text { Ihwa Mural Village, South Korea }\end{array}$ & 101,00 & 2020 & 1,349 & 1 \\
\hline 10 & Jacobsen (2012) & $\begin{array}{l}\text { Place brand equity: A model for establishing } \\
\text { the effectiveness of place brands }\end{array}$ & 100,00 & 2012 & 0,598 & 80 \\
\hline 11 & Moreno (2020) & $\begin{array}{l}\text { Sustainable city storytelling: cultural heritage } \\
\text { as a resource for a greener and fairer urban } \\
\text { development }\end{array}$ & 100,00 & 2020 & 0,283 & 0 \\
\hline 12 & $\begin{array}{l}\text { Askegaard \& } \\
\text { Kjeldgaard (2007) }\end{array}$ & $\begin{array}{l}\text { Here, there, and everywhere: Place branding } \\
\text { and gastronomical globalization in a } \\
\text { macromarketing perspective }\end{array}$ & 99,00 & 2007 & 0,736 & 129 \\
\hline 13 & $\begin{array}{l}\text { Warren \& Dinnie } \\
\text { (2018) }\end{array}$ & $\begin{array}{l}\text { Cultural intermediaries in place branding: } \\
\text { Who are they and how do they construct } \\
\text { legitimacy for their work and for themselves? }\end{array}$ & 97,00 & 2018 & 3,068 & 17 \\
\hline 14 & Hristova (2019) & $\begin{array}{l}\text { Architecture as a cultural sustainability factor } \\
\text { of Macedonian cities: The branding of Bitola }\end{array}$ & 94,00 & 2019 & 0,997 & 4 \\
\hline 15 & Farhat (2019) & $\begin{array}{l}\text { What Brand Is This Place? Place-Making and } \\
\text { the Cultural Politics of Downtown } \\
\text { Revitalization }\end{array}$ & 94,00 & 2019 & 0,466 & 4 \\
\hline 16 & Listerborn (2017) & $\begin{array}{l}\text { The flagship concept of the '4th urban } \\
\text { environment'. Branding and visioning in } \\
\text { Malmö, Sweden }\end{array}$ & 93,00 & 2017 & 1,035 & 23 \\
\hline 17 & $\begin{array}{l}\text { Maheshwari et al. } \\
\text { (2019) }\end{array}$ & $\begin{array}{l}\text { Investigating residents' attitudes of } 2016 \\
\text { Olympic Games: Examining socio-cultural, } \\
\text { economic and environmental dimensions }\end{array}$ & 92,00 & 2019 & 0,236 & 2 \\
\hline 18 & $\begin{array}{l}\text { Dudek- } \\
\text { Mańkowska \& } \\
\text { Grochowski (2019) }\end{array}$ & $\begin{array}{l}\text { From creative industries to the creative place } \\
\text { brand: some reflections on city branding in } \\
\text { Poland }\end{array}$ & 91,00 & 2019 & 0,279 & 1 \\
\hline 19 & $\begin{array}{l}\text { Scott \& Szili } \\
(2018)\end{array}$ & $\begin{array}{l}\text { Pop-up Polanyi: Cultural entrepreneurs and } \\
\text { the 'vacancy fix' }\end{array}$ & 87,00 & 2018 & 0,736 & 7 \\
\hline 20 & Chow (2017) & $\begin{array}{l}\text { Exploring creative class mobility: Hong } \\
\text { Kong creative workers in Shanghai and } \\
\text { Beijing }\end{array}$ & 87,00 & 2017 & 1,09 & 17 \\
\hline 21 & Molnár (2018) & $\begin{array}{l}\text { The business of urban coolness: Emerging } \\
\text { markets for street art }\end{array}$ & 82,00 & 2018 & 1,172 & 2 \\
\hline 22 & $\begin{array}{l}\text { Loftsdóttir et al. } \\
\text { (2017) }\end{array}$ & $\begin{array}{l}\text { Trapped in clichés: masculinity, films and } \\
\text { tourism in Iceland }\end{array}$ & 81,00 & 2017 & 1,024 & 11 \\
\hline 23 & Fung (2016) & $\begin{array}{l}\text { Strategizing for creative industries in China: } \\
\text { Contradictions and tension in nation branding }\end{array}$ & 78,00 & 2016 & 0,927 & 18 \\
\hline 24 & Navarro (2016) & $\begin{array}{l}\text { Creative industries and Britpop: the } \\
\text { marketisation of culture, politics and national } \\
\text { identity }\end{array}$ & 75,00 & 2015 & 0,904 & 15 \\
\hline 25 & $\begin{array}{l}\text { Oliveira \& Padilla } \\
(2017)\end{array}$ & $\begin{array}{l}\text { Integrating superdiversity in urban } \\
\text { governance: The case of inner-city Lisbon }\end{array}$ & 74,00 & 2017 & 1,507 & 4 \\
\hline 26 & Romão (2017) & $\begin{array}{l}\text { Are creative cities good places for creative } \\
\text { people? Notes on the social conditions for } \\
\text { cultural production in contemporary economy }\end{array}$ & 74,00 & 2017 & 0,197 & 4 \\
\hline
\end{tabular}




\begin{tabular}{|c|c|c|c|c|c|c|}
\hline No. & Authors & $\begin{array}{c}\text { Title } \\
\end{array}$ & InOrdinatio & Year & $\mathbf{F i}$ & $\mathbf{C i}$ \\
\hline 27 & Marsh (2016) & $\begin{array}{l}\text { Branding Brazil through cultural policy: Rio } \\
\text { de Janeiro as a creative, audiovisual city }\end{array}$ & 71,00 & 2016 & 0,927 & 11 \\
\hline 28 & $\begin{array}{l}\text { Jelinčić \& Vukić } \\
\text { (2015) }\end{array}$ & $\begin{array}{l}\text { Creative Industries as carriers of urban } \\
\text { identity and drivers of development: from } \\
\text { directional towards participative branding }\end{array}$ & 56,00 & 2015 & 0,391 & 6 \\
\hline 29 & Yue (2006) & $\begin{array}{l}\text { Cultural governance and creative industries in } \\
\text { Singapore }\end{array}$ & 45,00 & 2006 & 0,607 & 85 \\
\hline 30 & Allon (2013) & Ghosts of the open city & 44,00 & 2013 & 0,466 & 14 \\
\hline 31 & Cudny (2014) & $\begin{array}{l}\text { The Influence of the Komisarz Alex TV } \\
\text { Series on the Development of Lodz (Poland) } \\
\text { in the Eyes of City Inhabitants }\end{array}$ & 43,00 & 2014 & 0,693 & 3 \\
\hline 32 & Maher et al. (2013) & $\begin{array}{l}\text { Policy measures for creating an integrated } \\
\text { and brand-focused innovation system for film } \\
\text { industries in shadow nations: An application } \\
\text { to Australia's national film industry }\end{array}$ & 34,00 & 2013 & 0,2 & 4 \\
\hline 33 & $\begin{array}{l}\text { Karachalis \& } \\
\text { Deffner (2012) }\end{array}$ & $\begin{array}{l}\text { Rethinking the connection between creative } \\
\text { clusters and city branding: The cultural axis } \\
\text { of piraeus street in athens }\end{array}$ & 29,00 & 2012 & 0,257 & 9 \\
\hline 34 & McElroy (2011) & $\begin{array}{l}\text { Putting the landmark back into television: } \\
\text { Producing place and cultural value in Cardiff }\end{array}$ & 22,00 & 2011 & 0,279 & 12 \\
\hline 35 & Yessenova (2011) & $\begin{array}{l}\text { Nomad for export, not for domestic } \\
\text { consumption: Kazakhstan's arrested } \\
\text { endeavour to 'put the country on the map' }\end{array}$ & 20,00 & 2011 & 0,101 & 10 \\
\hline 36 & Jacobsen (2010) & $\begin{array}{l}\text { Urban place brands and the location of } \\
\text { creative industries: A model for measuring } \\
\text { place-brand equity }\end{array}$ & 9,00 & 2010 & 0,527 & 9 \\
\hline 37 & Brabazon (2009) & $\begin{array}{l}\text { Brand Wellington: When city imaging is } \\
\text { GLAMed: A personal view }\end{array}$ & 2,00 & 2009 & 0,279 & 12 \\
\hline 38 & Liu \& Ko (2010) & $\begin{array}{l}\text { A local city to a creative city: An } \\
\text { examination of Taichung, Taiwan }\end{array}$ & 2,00 & 2010 & 0,17 & 2 \\
\hline 39 & $\begin{array}{l}\text { Lange \& Stöber } \\
\text { (2008) }\end{array}$ & $\begin{array}{l}\text { "Die Stadt ist der Star": Vergleiche von } \\
\text { Place-Making-Prozesse Durch die } \\
\text { Kreativwirtschaft in Berlin und Kopenhagen }\end{array}$ & $-17,00$ & 2008 & 0,17 & 3 \\
\hline
\end{tabular}

Source: Elaborated by the authors.

Phase 8 (Finding the full papers) and Phase 9 (Final reading and systematic analysis of the papers) are straightforward tasks. They are the end of Methodi Ordinatio, but the very beginning of our content analysis.

\subsection{Content analysis and oblique approach}

Content analyses reduce "the complexity of a collection of texts" and "involves counting and comparisons, usually of keywords or content, followed by the interpretation of the underlying context" (Bauer, 2000, p. 132; Hsieh \& Shannon, 2005, p. 1277). As Braun and Clarke (2012, p. 61) imply: richness "can be found in even brief extracts of text."

Our content analysis was built in three steps. We first analyzed the co-occurrence of keywords using VOSviewer (Figure 3), developed by van Eck \& Waltman (2010). 


\section{Figure 3}

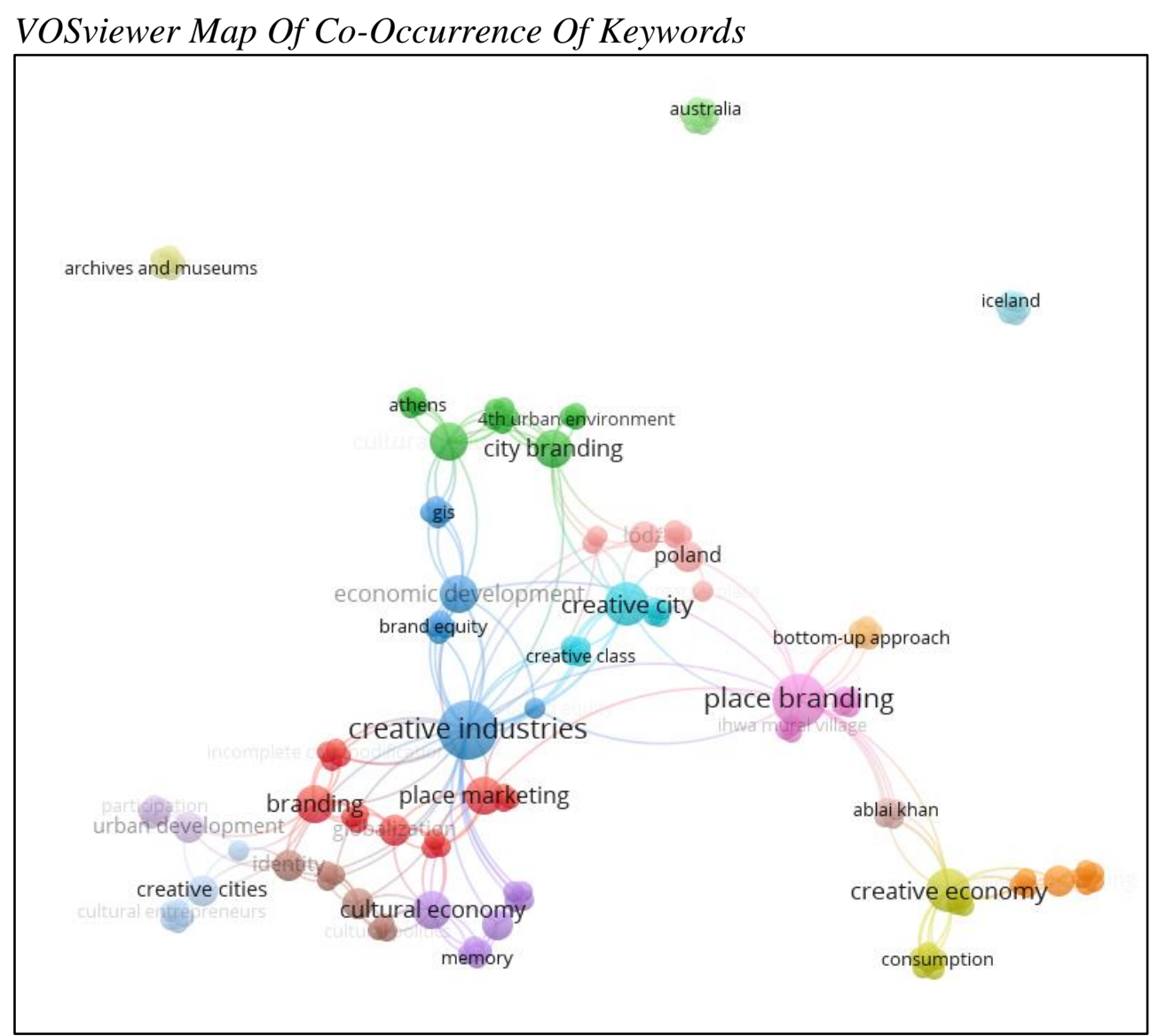

Source: Elaborated by the authors.

Secondly, we counted the use of the term soft power in each publication to find out whether authors make use of it. And thirdly, we analyzed the content of each article, looking for oblique uses of soft power (Table 2). By oblique, we mean indirect, not-straightforward.

It is worth mentioning that, methodologically, Kay (2011) understands obliquity as a process of experiment and discovery for achieving objectives indirectly. From this perspective, one could say that the ideas behind place branding and soft power are rather oblique, once their conceptual relationships are not direct - and, according to Rookwood (2019) - still in the process of formulation by both practitioners and scholars.

At any rate, what Kay (2011) calls an "oblique approach" seems to be an interesting method for the objectives of this research because it takes into account the subtleness and richness of complex content. 
Table 2

Content Analysis With an Oblique Approach of the resulting papers

\begin{tabular}{|c|c|c|}
\hline No. & $\begin{array}{l}\text { Use of } \\
\text { the term } \\
\text { "soft } \\
\text { power" }\end{array}$ & Textual excerpts that directly or obliquely refer to soft power \\
\hline 1 & 0 & $\begin{array}{l}\text { "One objective [of heritage-industry programs, which manages historical sites, buildings and } \\
\text { museums] is to attract increased numbers of visitors from other areas. Another, and possibly } \\
\text { more important goal, is to enhance the image and prestige of particular places so as to draw in } \\
\text { upscale investors and the skilled high-wage workers who follow in their train." (Scott, 2004, } \\
\text { p. 464) }\end{array}$ \\
\hline 2 & 0 & $\begin{array}{l}\text { "“Contemporary models of development argue that in order to attract people, cities must } \\
\text { cultivate places (and images of those places) that offer the qualities that people want in a place } \\
\text { to live and work (See Brooks, 2000; Glaeser et al., 2000; Florida, 2002; Clark, 2004)." (Currid } \\
\text { \& Williams, 2010, p. 427) }\end{array}$ \\
\hline 3 & 0 & $\begin{array}{l}\text { "Thus, 'terroir' is a concept that recognizes a 'sense of place' that }[\ldots] \text { can be linked to the } \\
\text { creative and artistic characteristics of the place, and are intrinsic to place identity and image } \\
\text { (Lee and Wall, 2014). Thus, a terroir is a well-defined and highly specialized place with } \\
\text { distinctive cultural characteristics and associated products (Croce and Perri, 2010). Residents } \\
\text { and visitors are attracted to such places that have established a unique cultural and artistic } \\
\text { landscape that can be used to create a distinctive place identity and image." (Lee et al., 2015, } \\
\text { p. 135) }\end{array}$ \\
\hline 4 & 4 & $\begin{array}{l}\text { "Following this trend, Japanese politicians began to circulate the idea of creating soft power } \\
\text { through the Cool Japan phenomenon. Statements and speeches became strategy documents, } \\
\text { measures, and funding decisions, and anime and manga began to be used in cultural } \\
\text { diplomacy." (Valaskivi, 2013, p. 488) }\end{array}$ \\
\hline 5 & 0 & $\begin{array}{l}\text { "CPE [Cultural Political Economy - of architecture] would seek to position these buildings } \\
\text { relative to the "economic imaginary' (Jessop, 2004) of culture-led regeneration, which has } \\
\text { made extensive use of the ostensibly 'soft' elements of capitalism - based on information, } \\
\text { creativity, knowledge and cultural objects (Thrift, 1998; Sayer, 1999, 2001) - to 'sell cities' to } \\
\text { tourists and investors as desirable (Hall and Hubbard, 1998)." (Jones, 2009, p. 2532). }\end{array}$ \\
\hline 6 & 0 & $\begin{array}{l}\text { "Firstly, and this is important for city marketers, managers and other urban professionals not } \\
\text { only in Berlin, but worldwide, "place matters"-again. Our cities as already mentioned above } \\
\text { are not interchangeable, but have particular characteristics that when identified and influenced } \\
\text { properly can help them position themselves internationally, create distinctiveness and a } \\
\text { competitive advantage in the presumed international competition." (Lange et al., 2008, p. 538) }\end{array}$ \\
\hline 7 & 2 & $\begin{array}{l}\text { "Cultural diplomacy is being increasingly considered the medium in which nation states can } \\
\text { instrumentalize their cultural production and accomplish soft power goals. Analysts have } \\
\text { repeatedly underlined the importance of culture in place branding in globalized economies, } \\
\text { where culture can singularize products and assign them greater value." (Ulldemolins \& } \\
\text { Zamorano, 2015, p. 20) }\end{array}$ \\
\hline 8 & 0 & $\begin{array}{l}\text { "Cities invest in cultural development, arts, creative industries, festivals and other events to } \\
\text { develop a range of opportunities and as an overall strategy to engage in global urban } \\
\text { competition, behaving like companies who try to differentiate themselves in the market by } \\
\text { investing in creativity and sponsoring arts events." (Cudny et al., 2020, p. 1) }\end{array}$ \\
\hline 9 & 0 & $\begin{array}{l}\text { "When more images of murals are represented and (re)produced via diverse forms of media, it } \\
\text { generates a strong branding power to a place as 'the best photo spot', while such proliferation } \\
\text { of images accelerates the detachment of representation from the socioeconomic realities of the } \\
\text { place." (Oh, 2020, p. 2) }\end{array}$ \\
\hline 10 & 0 & - \\
\hline 11 & 0 & $\begin{array}{l}\text { "City planning has the power of shaping the thoughts, emotions and actions of its inhabitants } \\
\text { (Gallagher, 1993). Urban life showcases both sides: the dark one as places full of obstacles: } \\
\text { expensive, unhealthy, dangerous, exclusive and anonymous. The bright one, that of the } \\
\text { fascination, attraction, social encounter, collaboration, solidarity; the place that provides } \\
\text { knowledge, ideas, information, freedom, entertainment, emancipation. Facing the challenges } \\
\text { and making the most of the advantages is the way that leads to the main objective of a better } \\
\text { urban future: sustainability." (Rivero Moreno, 2020, p. 400). }\end{array}$ \\
\hline
\end{tabular}




Use of
the term
"soft
power" $\quad$ Textual excerpts that directly or obliquely refer to soft power

"For the people of Funen, the production and marketing of local produce of particular gastronomical quality is potentially a source of health, renewed lifestyles, and income. Economic benefits are not tied to the marketing and selling of the produce alone. They are also 120 linked to the derived profits from tourism, to the attraction of new citizens from other parts of the country because of the enhanced quality of life, and to the derived effects in terms of conferences, learning centers, and attractiveness of investments attached to becoming a 'center of excellence."' (Askegaard \& Kjeldgaard, 2007, p. 146)

"If we understand that place marketers, by way of their position at the centre of cultural representation, create specific identities that represent certain ways of seeing reality, and have

130 a certain degree of power over how reality is perceived by target audiences, we can infer that these identities might both reflect and reinforce perceptions that are grounded in particular hegemonic power structures (Morgan \& Pritchard, 1998)." (Warren \& Dinnie, 2018, p. 304) "To support the images of the places which we seek to project on the global cultural map, we need a deeper understanding of the role of the creative industries within the framework of the 140 national cultural strategy for sustainable development. The opening of the creative cities cultural platform is just one of the segments that can lead to a broader recognition of the creative industries as factors of economic development, where architecture can also express its manifold talents and competences." (Hristova, 2019, p. 235)

"As cities continue to reinvent their postindustrial economies, branding constitutes one "soft" 150 Strategy to actualize this program (Hubbard, 1996; Lash \& Urry, 1994; Short, Benton, Luce, \& creating cultural communities and spurring economic activity. Consequently, planning urban regeneration around the arts and entertainment has gained in popularity." (Farhat, 2019, p. 12). "The power of the urban imagination lies in its potential to be institutionalized in planning and its capacity to travel translocally. The City of Malmö is trying to market the city as a producer 160 of planning concepts, and to use the platform of the Nordic City Network to promote it, which is a think tank of urban and regional planners dedicated to developing Nordic cities as attractive, innovative, and competitive knowledge cities." (Listerborn, 2017, p. 25).

"The 2010 FIFA World Cup was considered as an opportunity for South Africa to reduce poverty by supporting improvement campaigns to living conditions of the historically disadvantaged and to re-design apartheid cities (Pillay and Bass, 2008). Furthermore, the 2008 Beijing Olympic Games was viewed by most as a way to narrow the cultural distance between China and the outside world (Zhou and Ap, 2009). The 2012 London Olympic Games brought several positive social impacts, such as sustainable living, respect and equality, and consequently provided better opportunities to the residents and wider communities." (Maheshwari et al., 2019, p. 295)

"The power of attraction of these cities varies. The strength of Warsaw - the capital city of

180 Poland - is demonstrated by the location of nearly $37 \%$ of creative firms registered in all cities - capitals of Polish regions." (Dudek-Mańkowska \& Grochowski, 2019, p. 285)

"As Lash and Urry (1994, p. 326) noted, the city is: ... remade or reimagined, often to attract flows of tourists or entrepreneurs .... What is distinct about the contemporary remaking of place are the following: the importance of image and especially (aesthetic) reflexivity of place. [...] Once facilitated into urban space, cultural entrepreneurs' affective and material labour is gathered together with state level tourism strategies to attract domestic and international travellers (see South Australian Government, 2017b).” (M. Scott \& Szili, 2018, p. 4).

"Mapping the field of studies on creative class mobility, Kong [Lily Kong, 2014] cites a number of transnational inquiries that test the validity of theorists' coupling of a lively, hip, and buzzing place and the drive to move there, or its flip side, when a place loses its attractiveness and the creative workforce leaves. There are studies that deliver confirmative but often complex evidence. In their study of Dublin's creative class, for instance, Bennett et al. (2009) find that "soft" factors play an important role, but only for a small minority, in deciding where to work." (Chow, 2017, p. 5)

\begin{tabular}{lll}
\hline 21 & 0 & - \\
\hline 22 & 0 & $\begin{array}{l}\text { "Waade and Jensen (2013) conclude that one of the conscious goals of highlighting the themes } \\
\text { associated with Nordic noir is to win international prices to facilitate the possibility of attracting }\end{array}$ \\
\hline
\end{tabular}




\begin{tabular}{|c|c|c|}
\hline No. & $\begin{array}{l}\text { Use of } \\
\text { the term } \\
\text { "soft } \\
\text { power" }\end{array}$ & Textual excerpts that directly or obliquely refer to soft power \\
\hline & & $\begin{array}{l}\text { further funding from abroad, thus reminding us that artistic and economic concerns are not } \\
\text { necessarily separate from each other." (Loftsdóttir et al., 2017, pp. 1237-1238) }\end{array}$ \\
\hline 23 & 13 & $\begin{array}{l}\text { "As this article demonstrates, soft power also has an internal dimension. Soft power is not an } \\
\text { international display of China's image through wealth or politics but is a kind of "capillary" } \\
\text { power that generates a made-in-China discourse that can penetrate the new generation } \\
\text { (Foucault, 1980). Through its culture industries, the state can stabilize internal politics and } \\
\text { social conditions." (Fung, 2016, p. 3017). }\end{array}$ \\
\hline 24 & 0 & $\begin{array}{l}\text { "In closing, this study suggests that youth consumerism and popular culture are utilised as a } \\
\text { crucial economic and political driving force in favour of party or government interests, thereby } \\
\text { politicising consumer habits and commodifying cultural products. Beyond that, governments } \\
\text { seem responsible for shaping the eventual impact of some successful cultural movements, thus } \\
\text { proving their ability for modelling culture and controlling social trends." (Navarro, 2016, p. 3) }\end{array}$ \\
\hline 25 & 0 & - \\
\hline 26 & 0 & $\begin{array}{l}\text { "In a globalized world, increasing competition for the attractiveness of skilled labour, efficient } \\
\text { companies and investment flows also reinforces the role of governance and public institutions, } \\
\text { aiming at the achievement of new forms of competitive advantage arising from the production } \\
\text { and dissemination of knowledge and creativity." (Romão, 2017, p. 52) }\end{array}$ \\
\hline 27 & 0 & $\begin{array}{l}\text { "In recent years, the concept of branding has evolved beyond the corporate world and its } \\
\text { meaning as an image or reputation to include other aspects of the marketization and } \\
\text { commodification of everyday life, as a strategy for international diplomacy, and as a form of } \\
\text { sociopolitical expression and organization (Aronczyk, 2013; Aronczyk \& Powers, 2010; } \\
\text { Arvidsson, 2006; Lury, 2004)." (Marsh, 2016, p. 3023) }\end{array}$ \\
\hline 28 & 0 & $\begin{array}{l}\text { "Creativity is difficult; it is difficult to be defined, to be measured, to be relied upon for the } \\
\text { economic development. Still, it is extremely powerful in stimulating changes in societies, } \\
\text { organizations and in changing directions in management, not to mention positive changes it } \\
\text { brings to individuals. It strongly influences our own identities as well as identities of smaller } \\
\text { or larger groups of societies which can lead to the creative city development." (Jelinčić \& } \\
\text { Vukić, 2015, p. 8). }\end{array}$ \\
\hline 29 & 0 & $\begin{array}{l}\text { Asian values are incorporated into Singapore's creative economy strategy through the creative } \\
\text { cluster that produces the New Asia brand as hegemonic cultural capital. [...] The incorporation } \\
\text { of Asian values into this cluster to create the New Asia cultural capital attests to how soft } \\
\text { infrastructure is also integral to the creative wealth of an economy. (Yue, 2006, p. 22) }\end{array}$ \\
\hline 30 & 0 & $\begin{array}{l}\text { "Since reunification Berlin has come to be celebrated as both a creative, cosmopolitan city (the } \\
\text { "new Berlin") and as a social and cultural project for demonstrating the diversity and openness } \\
\text { of the "new Germany." It also occupies a central role in the imaginary of "the new Europe", } \\
\text { and has been labeled the "European epicentre of youthful cool."" (Allon, 2013, pp. 291-292) }\end{array}$ \\
\hline 31 & 0 & $\begin{array}{l}\text { "Besides, the positive perception and the achievable brand of a city associated with film and } \\
\text { culture may make the city additionally attractive as a good place to locate new economic } \\
\text { investments (not necessarily film-related)." (Cudny, 2014, p. 40) }\end{array}$ \\
\hline 32 & 0 & - \\
\hline 33 & 0 & $\begin{array}{l}\text { "Neighbourhood or district packaging and branding can take different forms and serve various } \\
\text { objectives. Clearly it is not only a tool for attracting visitors, as it can create a common image } \\
\text { and a shared vision for its residents (Ashworth \& Kavaratzis 2010, Sneed et al. 2011)." } \\
\text { (Karachalis \& Deffner, 2012, pp. 92-93). }\end{array}$ \\
\hline 34 & 0 & $\begin{array}{l}\text { "In post-industrial societies, creative industries - together with the financial services and the } \\
\text { knowledge economy - have assumed prominence in government policy at local and national } \\
\text { levels and have been vaunted as sources of new forms of economic power and sustainability in } \\
\text { an increasingly competitive global marketplace." (McElroy, 2011, p. 182). }\end{array}$ \\
\hline 35 & 0 & $\begin{array}{l}\text { "A manufactured product - a film - was to foster Kazakhstan's image as a creative, innovative } \\
\text { economy. In other words, the function of the future film was to liberate the country from } \\
\text { anonymity by delivering a 'message [...] to the widest possible audience' (Van Ham 2008: } \\
129 \text { ) and brand it as an attractive place for international investors and tourists." (Yessenova, } \\
2011 \text {, p. 182) }\end{array}$ \\
\hline 36 & 0 & $\begin{array}{l}\text { "It is of interest whether the promotional element of the place-marketing mix, especially the } \\
\text { development of brands, can be effectively used to increase (foreign direct) investment inflows }\end{array}$ \\
\hline
\end{tabular}




\begin{tabular}{|c|c|c|}
\hline No. & $\begin{array}{l}\text { Use of } \\
\text { the term } \\
\text { "soft } \\
\text { power" }\end{array}$ & Textual excerpts that directly or obliquely refer to soft power \\
\hline & & $\begin{array}{l}\text { from the creative industries. According to Florida (2002), places having built strong and } \\
\text { dynamic brands have an easier task of attracting companies within the knowledge industries." } \\
\text { (Jacobsen, 2010, p. 278). }\end{array}$ \\
\hline 37 & 0 & $\begin{array}{l}\text { "While other cities may not experience the branding windfall of a Hollywood film, the planning } \\
\text { instigated in Wellington to prepare for a popular cultural opportunity is instructive. In aligning } \\
\text { creative industries, popular culture and city imaging theory, GLAMs [Galleries, Libraries, } \\
\text { Archives and Museums] move from a serious but understated part of place branding to a } \\
\text { facilitator for economic and social change." (Brabazon, 2009, p. 260). }\end{array}$ \\
\hline 38 & 0 & $\begin{array}{l}\text { "Since Florida's focus is on place competition and consumption, culture and the creative } \\
\text { industries turn out to be an instrumental sideshow that attracts creative workers, which attracts } \\
\text { hi-tech investors to cities (Peck, 2005; Pratt, 2008)." (Liu \& Ko, 2010, p. 112). }\end{array}$ \\
\hline 39 & 0 & - \\
\hline
\end{tabular}

Source: Elaborated by the authors.

\section{Results and discussion}

On Table 1, we have demonstrated that virtually all the articles (38/39) have positive values for the InOrdinatio equation (Phase 7), which means that they should be considered for further analysis, as recommended by the authors of the Methodi Ordinatio. In fact, they state that "the number of papers to be read is decided by the researcher" (Pagani et al., 2015, p. 2121) - certainly considering the numerical difference of publications in different areas of knowledge.

Inasmuch as of our portfolio is relatively small, we have decided to individually read and review the content of all the publications, performing Phase 9 of Methodi Ordinatio.

As seen on Table 2, the direct use the term soft power could be found in 3 papers only $(4,7$, and 23). In other four papers (10-21-25-39), no possible reference to the term, directly or indirectly made, could be found. As previously mentioned, this is expected and might stem from the fact that the term soft power portrays the image of places in terms of politics and international relations, whereas the variations of place branding mostly refer to market and economic dimensions (Johnson, 2018).

Almost all studies (34/36, with the exceptions of papers 32 and 39), however, somehow allude to the concept of soft power when they refer to attractiveness.

In section 2 (Theoretical background), we have demonstrated that the idea of attractiveness seems to be the common factor between the ideas behind nation branding and soft power. Joseph Nye has recently written that soft power functions "like a magnet" (2021, p. 201) and, in the past, Anholt replaced the term nation branding for national identity as a restatement, considering that branding "is a dangerously misleading phrase which seems to 
contain a promise that the images of countries can be directly manipulated using the techniques of commercial marketing communications" (Anholt, 2013, p. 1) and, therefore, a country's identity must be developed "to earn a reputation that is fair; true; powerful; attractive; genuinely useful to their economic, political, and social aims." (Anholt, 2013, p. 9).

From this standpoint, what our research ultimately demonstrates is that authors on place branding may not be used to the term soft power itself, but obliquely allude to its concept when they look at places as an object that fosters attractiveness through soft elements, as seen on the textual excerpts in Table 2.

For instance, when Warren \& Dinnie (2018, p. 304) - article 13 - say that place marketers "create specific identities that represent certain ways of seeing reality, and have a certain degree of power over how reality is perceived by target audiences", we understand that they are alluding to soft power and psychosociology. Or when Farhat (2019, p. 12) - paper 15 - state that "soft strategies have become central to creating cultural communities and spurring economic activity.", we posit that this is a subtle allusion to soft power, and future studies could investigate its relationship with urban planning.

Using this oblique approach, we inferred five un- or underexplored paths that relates power, places, and the attractiveness of creativity: psychosociology, labor mobility, urban planning, arts diplomacy, gastrodiplomacy, and geographical indications.

It is worth mentioning that inferences are not rare in scientific practice and are used when the interest is not in the description of the contents, but in the construction of relative knowledge (Bardin, 2011).

In due time, it is also important to highlight that the objective of this paper is "to present cross-disciplinary future research guidelines on soft power". Therefore, using the proposed methodology, our results fundamentally consist of interpretations of subtle allusions to soft power, and inferences on their relation to other fields of knowledge.

We tested our results by verifying whether the inferred guidelines have already been addressed and overlooked. As observed on the VOSviewer map (Figure 3), ["soft power"] is not a central keyword. Hence, in the following Figure 4, we use it as so and carry out a simple search on Scopus database, where the virtual absence of studies on those areas is illustrated.

On Table 3, we shortly describe each area of the proposed guidelines, relating them with the resulting papers from Methodi Ordinatio and their oblique references - previously confirmed using content analysis, in Table 2. 


\section{Figure 4}

\section{Array of Future Research Guidelines on Soft Power and Scopus Overview}

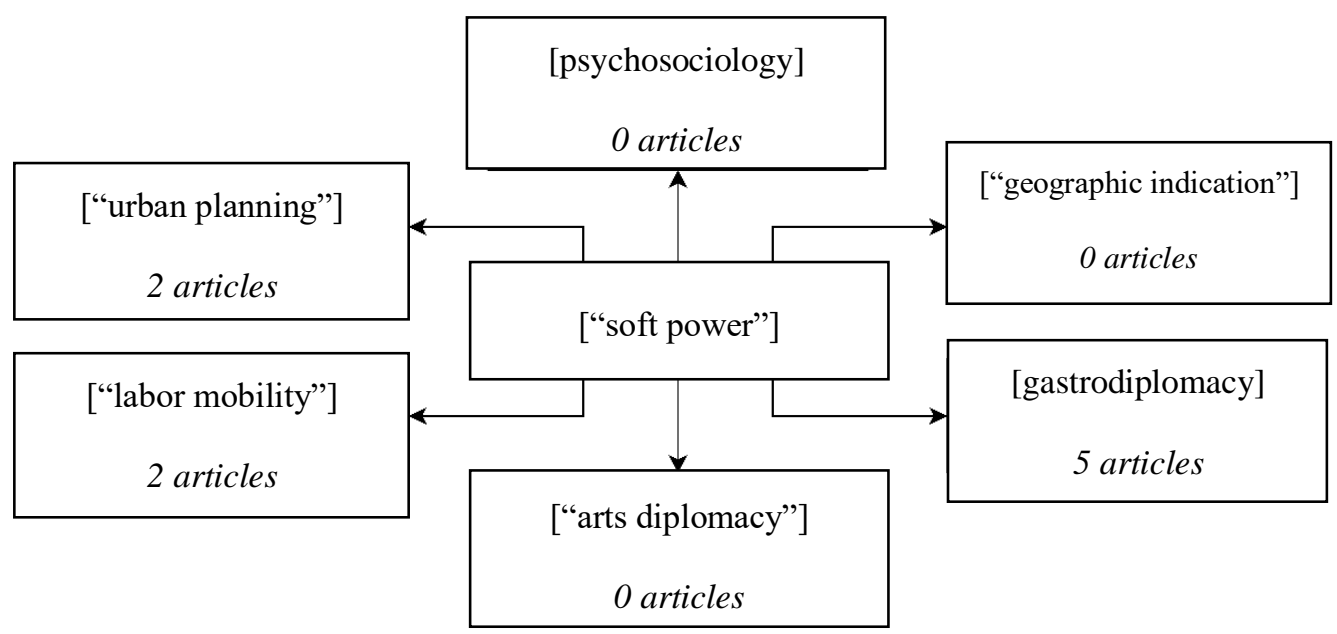

Source: Elaborated by the authors.

\section{Table 3}

Future research guidelines and their oblique references

\begin{tabular}{|c|c|c|}
\hline Area of knowledge & Short description & Oblique references \\
\hline Psychosociology & $\begin{array}{l}\text { It studies the ways in which subjective } \\
\text { experience is interwoven with social life. It } \\
\text { encompasses a wide range of subject matter, } \\
\text { including politics, nations and states, } \\
\text { communities, and collective life (APS, 2021). }\end{array}$ & $\begin{array}{l}\text { Jones (2009); Moreno (2020); } \\
\text { Warren \& Dinnie (2018); Listerborn } \\
\text { (2017); Scott \& Szili (2018); Marsh } \\
\text { (2016); Jelinčić \& Vukić (2015); Yue } \\
\text { (2006); Allon (2013); Karachalis \& } \\
\text { Deffner (2012) }\end{array}$ \\
\hline Labor mobility & $\begin{array}{l}\text { For Chow (2017), the dynamics of workers' } \\
\text { mobility is largely configured by both } \\
\text { concerns with employment situations and } \\
\text { place attractiveness. Places must try their best } \\
\text { to attract and retain talented workers. }\end{array}$ & $\begin{array}{l}\text { Scott (2004); Currid \& Williams } \\
\text { (2010); Lee et al. (2015); Askegaard } \\
\text { \& Kjeldgaard (2007); Dudek- } \\
\text { Mańkowska \& Grochowski (2019); } \\
\text { Scott \& Szili (2018); Chow (2017); } \\
\text { Romão (2017); Jacobsen (2010); Liu } \\
\text { \& Ko (2010) }\end{array}$ \\
\hline Urban planning & $\begin{array}{l}\text { The link between place branding and urban } \\
\text { planning has been recently studied by } \\
\text { Bonakdar \& Audirac (2020). For them, public } \\
\text { participation is fundamental in urban planning } \\
\text { policies as to generate, legitimize, and } \\
\text { authenticate the creation of urban imaginaries. }\end{array}$ & $\begin{array}{l}\text { Lange et al. (2008); Hristova (2019); } \\
\text { Farhat (2019); Listerborn (2017); } \\
\text { Maheshwari et al. (2019); Allon } \\
\text { (2013); Karachalis \& Deffner (2012) }\end{array}$ \\
\hline Arts diplomacy & $\begin{array}{l}\text { "Arts diplomacy is a response to the desires of } \\
\text { overseas publics" (Brown, 2020). It can be } \\
\text { defined as the use of art as an instrument of } \\
\text { creating powerful impressions in audiences } \\
\text { from different places throughout the world. }\end{array}$ & $\begin{array}{l}\text { Lee et al. (2015); Valaskivi (2013); } \\
\text { Cudny et al. (2020); Oh (2020); } \\
\text { Loftsdóttir et al. (2017); Navarro } \\
\text { (2016); Brabazon (2009) }\end{array}$ \\
\hline Gastrodiplomacy & $\begin{array}{l}\text { It is a term that exists in the realm of cultural } \\
\text { diplomacy. It refers to how food may heighten } \\
\text { awareness to the distinctness of a nation's } \\
\text { unique culture. (Rockower, 2012) }\end{array}$ & Askegaard \& Kjeldgaard (2007); \\
\hline
\end{tabular}




\begin{tabular}{lll}
\hline Area of knowledge & \multicolumn{1}{c}{ Short description } & Oblique references \\
\hline & $\begin{array}{l}\text { Lee et al. refers to terroir, a familiar French } \\
\text { terminology on the theme of Geographic }\end{array}$ \\
$\begin{array}{l}\text { Geographical } \\
\text { Indications }\end{array}$ & $\begin{array}{l}\text { "ications. For Herman (2009, p. 48), terroir, } \\
\text { narratives that, shared, enable us to consume } \\
\text { the flavors and pleasures of a place." }\end{array}$ & \\
&
\end{tabular}

Source: Elaborated by the authors.

\section{Conclusions and future research agenda}

In this paper, we presented a systematic literature review, composed of a content analysis with oblique approach, on the correlation between place branding, creative industry, and soft power from the largest abstract and citation database of peer-reviewed literature, Scopus. This review is quite extensive, and explores genuinely relevant publications on the topics, as demonstrated via the equation InOrdinatio, from the Methodi Ordinatio.

The main objective of our work was to build an interdisciplinary future research agenda. When it comes to soft power, place branding and creative industries, it seems that this interdisciplinarity might extend to other fields of knowledge.

In this paper, we presented six ones, and they were obtained by interpreting subtle allusions in the reviewed literature. In this section, we also present two potential areas for further investigation, inferred from indirect observations.

On the subject of Psychosociology, we understand that one interesting topic for future research is the social imaginary and collective memory of places and how they reflect place's soft power. Considering that branding involves fictionalization, mythmaking, and creating profitable affective associations with products, places, or people (Marsh, 2016), imagination and memory may be a particular (yet collective) source of soft power.

As for Labor Mobility and Urban Planning, we can infer that creative cities hold soft power over others in terms of talent attraction and retention, and future studies could explore what high-skilled workers expect from then, especially in the current context of remote work.

Arts Diplomacy and Gastrodiplomacy are within what is already known as cultural diplomacy. They are relatively new terms, and future research on soft power could explore how globally known arts and food might be attractive to some specific countries, but not others, considering that they provide highly subjective experiences and memories.

Decisively, Geographical Indications might be an interesting topic for investigation in terms of place branding and soft power. They are non-transferable collective instruments that can connect people and products with their cultural and historical heritage (Bowen \& Zapata, 
2009), attracting people from different places to live part of their own modus vivendi. Here, future research could address how the consumption of products from certified regions may shape people's habits and behaviors towards places.

As previously mentioned, our observations allow us to infer two additional paths for future research.

We have decided to call the first one "misguided interpretations of place branding". For different people from different parts of the world, it is possible that the symbols printed on brands and places could be related to countries other than the original "holder" of that image. In some places, the glamour of the Gucci brand, for example, could be more associated in people's minds to the United States, Hollywoodian celebrities, and ostentatious musicians than to the sophistication of the Italian fashion.

It could also be worth studying the "dynamics of access to place image through creative and traditional products", shedding light on how they increase or decrease soft power. Counterfeit products are one good example here: knockoffs are mostly present on emerging economies and attempt to (or inadvertently do) print the image of a foreign country. In Brazil, for instance, one can say that people are getting to know new places and cultures throughout the world when they have access to products such as European soccer jerseys and United States' basketball clothing, with their city-named teams (Barcelona, Manchester City, Paris SaintGermain, Los Angeles Lakers, Boston Celtics, and so on). While these products (albeit their low quality) may stimulate positive associations with these places, quite the opposite can happen with substandard and falsified products that do not brand a place on them, where Brazilians may promptly associate them to China. Low-quality technological gadgets and gizmos, for example, may trigger negative images of the Asian country.

Our main conclusion is that although the branch of knowledge of soft power has been predominantly looked at with a focus on the political perspective of countries, it is also a relatively new thought that has percolated through the minds of scholars from marketing research. Soft power should then be seen as an interdisciplinary subject, and there are several interesting research questions that can be derived from this study.

In drawing to a close, it is important to highlight that this paper indeed presents theoretical challenges for scholars, but also puts forward underexplored areas by practitioners and policy-makers, who could put it to good use for the image planning of cities, regions, and countries. From our standpoint, the areas involving arts and gastronomy seem to be feasible 
initiatives for the short-term, meanwhile practicable actions towards psychosociology, labor mobility, urban planning and geographical indications may be more time and cost consuming.

\section{Limitations}

A major source of limitation of this study is that it uses only one scientific database. Moreover, the oblique approach for literature review has not been perfectly described as a scientific method, and content analysis may be subject to assumptions and biases.

Also, in spite of the fact that Methodi Ordinatio is a robust method for finding highly relevant scientific publications, it is impractical for books, book chapters, or conference papers, and, for this reason, this kind of material has not been analyzed in this study, although it may contain further and interesting paths for a research agenda.

This is to say that future research could indeed fruitfully explore the new paths that this study has revealed. But researchers - and practitioners - should always keep in mind that soft power, creative industries, and place branding are interdisciplinary objects of study, and that there is much more of this uncharted world to explore. Just like Alexander von Humboldt once has.

\section{Acknowledgments}

We gratefully acknowledge the financial support of the Coordination for the Improvement of Higher Education Personnel (CAPES), in Brazil.

\section{References}

Allon, F. (2013). Ghosts of the open city. Space and Culture, 16(3), 288-305. https://doi.org/10.1177/1206331213487054

Anholt, S. (2005). Brand New Justice: How Branding Places and Products Can Help the Developing World. 173.

Anholt, S. (2010). Places: Identity, Image and Reputation (1st ed.). Palgrave Macmillan.

Anholt, S. (2013). Beyond Nation Brand: The Role of Image and Identity in International Relations. Exchange: The Journal of Public Diplomacy, 2(1).

s://surface.syr.edu/exchange/vol2/iss1/1

APS - The Association for Psychosocial Studies. (2021). What is Psychosocial Studies? http://www.psychosocial-studies-association.org/about/ 
Askegaard, S., \& Kjeldgaard, D. (2007). Here, there, and everywhere: Place branding and gastronomical globalization in a macromarketing perspective. Journal of Macromarketing, 27(2), 138-147. https://doi.org/10.1177/0276146707300068

Bardin, L. (2011). Análise de Conteúdo. Edições 70.

Bauer, M. W. (2000). Classical Content Analysis: a Review. In M. W. Bauer \& G. Gaskell (Eds.), Qualitative Researching with Text, Image and Sound (p. 374). SAGE Publications.

Bell, F. (2016). Looking beyond place branding: the emergence of place reputation. Journal of Place Management and Development, 9(3), 247-254.

Boisen, M., Terlouw, K., Groote, P., \& Couwenberg, O. (2017). Reframing place promotion, place marketing, and place branding - moving beyond conceptual confusion. Cities, 80(January), 4-11. https://doi.org/10.1016/j.cities.2017.08.021

Bonakdar, A., \& Audirac, I. (2020). City Branding and the Link to Urban Planning: Theories, Practices, and Challenges. Journal of Planning Literature, 35(2), 147-160. https://doi.org/10.1177/0885412219878879

Bowen, S., \& Zapata, A. V. (2009). Geographical indications, terroir, and socioeconomic and ecological sustainability: The case of tequila. Journal of Rural Studies, 25(1), 108-119. https://doi.org/https://doi.org/10.1016/j.jrurstud.2008.07.003

Brabazon, T. (2009). Brand Wellington: When city imaging is GLAMed: A personal view. Place Branding and Public Diplomacy, 5(4), 260-275. https://doi.org/10.1057/pb.2009.22

Braun, V., \& Clarke, V. (2012). Thematic Analysis. In H. M. Cooper \& P. M. Camic (Eds.), APA Handbook of Research Methods in Psychology. American Psychological Association.

Brown, J. (2020). Arts Diplomacy: The Neglected Aspect of Cultural Diplomacy. In N. Snow \& N. J. Cull (Eds.), Routledge Handbook of Public Diplomacy. Routledge.

Cambridge Dicionary. (2018). https://dictionary.cambridge.org/dictionary/germanenglish/fernweh

Chow, Y. F. (2017). Exploring creative class mobility: Hong Kong creative workers in Shanghai and Beijing. Eurasian Geography and Economics, 58(4), 361-385. https://doi.org/10.1080/15387216.2017.1365311

Cudny, W. (2014). Vliv televizního seriálu "Komisař Alex" na rozvoj Lodže (Polsko) očima jeho obyvatel. Moravian Geographical Reports, 22(1), 33-43. https://doi.org/10.2478/mgr2014-0004

Cudny, W., Comunian, R., \& Wolaniuk, A. (2020). Arts and creativity: A business and branding strategy for Lodz as a neoliberal city. Cities, 100. https://doi.org/10.1016/j.cities.2020.102659

Currid, E., \& Williams, S. (2010). The geography of buzz: Art, culture and the social milieu in Los Angeles and New York. Journal of Economic Geography, 10(3), 423-451. https://doi.org/10.1093/jeg/lbp032 
Dudek-Mańkowska, S., \& Grochowski, M. (2019). From creative industries to the creative place brand: some reflections on city branding in Poland. Place Branding and Public Diplomacy, 15(4), 274-287. https://doi.org/10.1057/s41254-019-00141-7

Fan, Y. (2010). Branding the nation: Towards a better understanding. Place Branding and Public Diplomacy, 6(2), 97-103. https://doi.org/10.1057/pb.2010.16

Farhat, R. R. (2019). What Brand Is This Place? Place-Making and the Cultural Politics of Downtown Revitalization. Space and Culture, 22(1), 34-49. https://doi.org/10.1177/1206331217751778

Florek, M., Hereźniak, M., \& Augustyn, A. (2021). Measuring the effectiveness of city brand strategy. In search for a universal evaluative framework. Cities, 110(December 2020). https://doi.org/10.1016/j.cities.2020.103079

Fung, A. (2016). Strategizing for creative industries in China: Contradictions and tension in nation branding. International Journal of Communication, 10, 3004-3021.

Galeeva, D. (2020). Putting tatars on the map: The place branding versus soft power of Tatarstan. Place Branding and Public Diplomacy. https://doi.org/10.1057/s41254-020-001690

Hankinson, G. (2010). Place branding research: A cross-disciplinary agenda and the views of practitioners. Place Branding and Public Diplomacy, 6(4), 300-315.

https://doi.org/10.1057/pb.2010.29

Hao, A. W., Paul, J., Trott, S., Guo, C., \& Wu, H. H. (2019). Two decades of research on nation branding: a review and future research agenda. International Marketing Review, 38(1), 46-69. https://doi.org/10.1108/IMR-01-2019-0028

Herman, B. L. (2009). Drum Head Stew: The Power and Poetry of Terroir. Southern Cultures, 15(4), 36-49.

Hristova, A. (2019). Architecture as a cultural sustainability factor of Macedonian cities: The branding of Bitola. Sustainable Development, 27(2), 227-236. https://doi.org/10.1002/sd.1881

Hsieh, H. F., \& Shannon, S. E. (2005). Three approaches to qualitative content analysis. Qualitative Health Research, 15(9), 1277-1288. https://doi.org/10.1177/1049732305276687

Jacobsen, B. P. (2010). Urban place brands and the location of creative industries: A model for measuring place-brand equity. Urban Research and Practice, 3(3), 275-298. https://doi.org/m

Jelinčić, D. A., \& Vukić, F. (2015). Le industrie creative come artefici dell'identità urbana e motori dello sviluppo: Dal branding direzionale a quello partecipativo. Annales-Anali Za Istrske in Mediteranske Studije - Series Historia et Sociologia, 25(3), 527-536.

Johnson, M. A. M. A. (2018). Culture as soft power: Digital branding by catalonia, the basque country and Scotland. Catalan Journal of Communication and Cultural Studies, 10(1), 115124. https://doi.org/10.1386/cjcs.10.1.115_1 
Jones, P. (2009). Putting architecture in its social place: A cultural political economy of architecture. Urban Studies, 46(12), 2519-2536. https://doi.org/10.1177/0042098009344230

Kahraman, E. (2016). A Methodological Approach to Nation Branding. In N. Chitty, L. Ji, G. Rawnsley, \& C. Hayden (Eds.), The Routledge Handbook of Soft Power (1st ed., pp. 93-103). Routledge.

Karachalis, N., \& Deffner, A. (2012). Rethinking the connection between creative clusters and city branding: The cultural axis of piraeus street in athens. Quaestiones Geographicae, 31(4), 87-97. https://doi.org/10.2478/v10117-012-0038-0

Kay, J. (2011). Obliquity: Why our goals are best achieved indirectly. The Penguin Press.

Lange, B., Kalandides, A., Stöber, B., \& Mieg, H. A. (2008). Berlin's creative industries: Governing creativity? Industry and Innovation, 15(5), 531-548.

https://doi.org/10.1080/13662710802373981

Lee, A. H. J., Wall, G., \& Kovacs, J. F. (2015). Creative food clusters and rural development through place branding: Culinary tourism initiatives in Stratford and Muskoka, Ontario, Canada. Journal of Rural Studies, 39, 133-144. https://doi.org/10.1016/j.jrurstud.2015.05.001

Lee, S. T. (2021). Film as cultural diplomacy: South Korea's nation branding through Parasite (2019). Place Branding and Public Diplomacy. https://doi.org/10.1057/s41254-020-00192-1

Listerborn, C. (2017). The flagship concept of the '4th urban environment'. Branding and visioning in Malmö, Sweden. Planning Theory and Practice, 18(1), 11-33. https://doi.org/10.1080/14649357.2016.1264615

Liu, L. W., \& Ko, P. Y. (2010). A local city to a creative city: An examination of Taichung, Taiwan. International Journal of Sustainable Development, 13(1-2), 111-121. https://doi.org/10.1504/IJSD.2010.035103

Loftsdóttir, K., Kjartansdóttir, K., \& Lund, K. A. (2017). Trapped in clichés: masculinity, films and tourism in Iceland. Gender, Place and Culture, 24(9), 1225-1242. https://doi.org/10.1080/0966369X.2017.1372383

Lucarelli, A., \& Berg, P. O. (2011). City branding: A state-of-the-art review of the research domain. Journal of Place Management and Development, 4(1), 9-27. https://doi.org/10.1108/17538331111117133

Lucarelli, A., \& Giovanardi, M. (2016). The political nature of brand governance: A discourse analysis approach to a regional brand building process. Journal of Public Affairs, 16(1), 1627. https://doi.org/10.1002/pa.1557 
Maheshwari, V., Giraldi, J. de M. E., \& Montanari, M. G. (2019). Investigating residents' attitudes of 2016 Olympic Games: Examining socio-cultural, economic and environmental dimensions. Journal of Place Management and Development, 12(3), 291-313. https://doi.org/10.1108/JPMD-08-2018-0059

Marc, I. (2019). Around the world: France's new popular music diplomacy. Modern and Contemporary France, 28(3), 253-270. https://doi.org/10.1080/09639489.2019.1682533

Mariutti, F. G., \& Giraldi, J. de M. E. (2021). Branding cities, regions and countries: the roadmap of place brand equity. RAUSP Management Journal, 56(2), 202-216. https://doi.org/10.1108/rausp-06-2020-0131

Mariutti, F. G., \& Tench, R. (2016). How does Brazil measure up? Comparing rankings through the lenses of nation brand indexes. Place Branding and Public Diplomacy, 12(1), 17-31. https://doi.org/10.1057/pb.2015.19

Marsh, L. L. (2016). Branding Brazil through cultural policy: Rio de Janeiro as a creative, audiovisual city. International Journal of Communication, 10, 3022-3041.

Mattern, J. B. (2005). Why "Soft Power" isn't so soft: Representational force and attraction in world politics. Millennium: Journal of International Studies, 33(3), 583-612. https://doi.org/10.1177/03058298050330031601

McElroy, R. (2011). Putting the landmark back into television: Producing place and cultural value in Cardiff. Place Branding and Public Diplomacy, 7(3), 175-184. https://doi.org/10.1057/pb.2011.20

Navarro, B. (2016). Creative industries and Britpop: the marketisation of culture, politics and national identity. Consumption Markets and Culture, 19(2), 228-243. https://doi.org/10.1080/10253866.2015.1068168

Nye, J. S. (1990). Bound to lead: the changing nature of American power. Basic Books.

Nye, J. S. (2004). Soft Power: The means to success in world politics (1st ed.). PublicAffairs.

Nye, J. S. (2021). Soft power: the evolution of a concept. Journal of Political Power, 14(1), 196-208. https://doi.org/10.1080/2158379X.2021.1879572

Oh, Y. (2020). From concrete walls to digital walls: transmedia construction of place myth in Ihwa Mural Village, South Korea. Media, Culture and Society, 42(7-8), 1326-1342. https://doi.org/10.1177/0163443720916410

Pagani, R. N., Kovaleski, J. L., \& Resende, L. M. (2015). Methodi Ordinatio: a proposed methodology to select and rank relevant scientific papers encompassing the impact factor, number of citation, and year of publication. Scientometrics, 105(3), 2109-2135. https://doi.org/10.1007/s11192-015-1744-X

Pedeliento, G., \& Kavaratzis, M. (2019). Bridging the gap between culture, identity and image: a structurationist conceptualization of place brands and place branding. Journal of Product and Brand Management, 28(3), 348-363. https://doi.org/10.1108/JPBM-01-2018-1735 
Rabêlo Neto, A., Sousa-Filho, J. M. de, \& Carneiro Lima, A. (2021). Internationalization of culture and soft power. European Business Review. https://doi.org/10.1108/EBR-09-20190240

Rius Ulldemolins, J., \& Zamorano, M. M. (2015). Spain's nation branding project Marca España and its cultural policy: the economic and political instrumentalization of a homogeneous and simplified cultural image. International Journal of Cultural Policy, 21(1), 20-40. https://doi.org/10.1080/10286632.2013.877456

Rivero Moreno, L. D. L. D. (2020). Sustainable city storytelling: cultural heritage as a resource for a greener and fairer urban development. Journal of Cultural Heritage Management and Sustainable Development. https://doi.org/10.1108/JCHMSD-05-2019-0043

Rockower, P. S. (2012). Recipes for gastrodiplomacy. Place Branding and Public Diplomacy, 8(3), 235-246. https://doi.org/10.1057/pb.2012.17

Romão, J. (2017). Are creative cities good places for creative people? Notes on the social conditions for cultural production in contemporary economy. Quality Innovation Prosperity, 21(1), 49-60. https://doi.org/10.12776/QIP.V21I1.777

Rookwood, J. (2019). Access, security and diplomacy: Perceptions of soft power, nation branding and the organisational challenges facing Qatar's 2022 FIFA World Cup. Sport, Business and Management: An International Journal, 9(1), 26-44. https://doi.org/10.1108/SBM-02-2018-0016

Scott, A. (2004). Cultural-products industries and urban economic development: Prospects for growth and market contestation in global context. Urban Affairs Review, 39(4), 461-490. https://doi.org/10.1177/1078087403261256

Scott, M., \& Szili, G. (2018). Pop-up Polanyi: Cultural entrepreneurs and the 'vacancy fix.' City, Culture and Society, 14, 22-27. https://doi.org/10.1016/j.ccs.2017.12.005

Skinner, H. (2008). The emergence and development of place marketing's confused identity. Journal of Marketing Management, 24(9-10), 915-928. https://doi.org/10.1362/026725708X381966

Valaskivi, K. (2013). A brand new future? Cool Japan and the social imaginary of the branded nation. Japan Forum, 25(4), 485-504. https://doi.org/10.1080/09555803.2012.756538

Van Eck, N. J., \& Waltman, L. (2010). Software survey: VOSviewer, a computer program for bibliometric mapping. Scientometrics, 84(2), 523-538. https://doi.org/10.1007/s11192-0090146-3

Wang, J. (2013). Shaping China's Global Imagination: Branding Nations at the World Expo. In J. Wang (Ed.), Shaping China's Global Imagination: Public Diplomacy through Communication. Palgrave Macmillan. 
Warren, G., \& Dinnie, K. (2018). Cultural intermediaries in place branding: Who are they and how do they construct legitimacy for their work and for themselves? Tourism Management, 66, 302-314. https://doi.org/10.1016/j.tourman.2017.12.012

Wulf, A. (2015). The Invention of Nature: Alexander Von Humboldt's New World - Andrea Wulf - Google Books. Alfred A. Knopf.

Yessenova, S. (2011). Nomad for export, not for domestic consumption: Kazakhstan's arrested endeavour to 'put the country on the map.' Studies in Russian and Soviet Cinema, 5(2), 181203. https://doi.org/10.1386/srsc.5.2.181_1

Yue, A. (2006). Cultural governance and creative industries in Singapore. International Journal of Cultural Policy, 12(1), 17-33. https://doi.org/10.1080/10286630600613176 


\title{
DIRETRIZES PARA PESQUISAS FUTURAS SOBRE SOFT POWER: UMA ABORDAGEM OBLÍQUA DA LITERATURA SOBRE O ENTRELAÇAMENTO ENTRE INDÚSTRIAS CRIATIVAS E MARCAS DE LUGAR
}

\author{
Rodolfo Paião de Campos \\ Faculdade de Economia, Administração e Contabilidade de Ribeirão Preto - Universidade de São Paulo (FEA-RP/USP) \\ Ribeirão Preto, São Paulo - Brasil. \\ rodolfo.decampos@usp.br \\ Simone Vasconcelos Ribeiro Galina \\ Faculdade de Economia, Administração e Contabilidade de Ribeirão Preto - Universidade de São Paulo (FEA-RP/USP). \\ Ribeirão Preto, São Paulo - Brasil. \\ svgalina@usp.br \\ Janaina de Moura Engracia Giraldi \\ Faculdade de Economia, Administração e Contabilidade de Ribeirão Preto - Universidade de São Paulo (FEA-RP/USP) \\ Ribeirão Preto, São Paulo - Brasil. \\ jgiraldi@usp.br
}

Objetivo: O objetivo deste artigo é apresentar diretrizes interdisciplinares para pesquisas futuras sobre soft power, analisando seu entrelaçamento com indústrias criativas e place branding.

Metodologia: Trata-se de uma revisão sistemática da literatura utilizando o Methodi Ordinatio na base de dados Scopus. Os artigos são classificados de acordo com sua relevância e revisados por meio de técnicas de análise de conteúdo e abordagem oblíqua.

Principais resultados: Embora vários autores não façam uso do termo soft power em si, a maioria deles faz alusões oblíquas ao seu conceito, de onde tiramos inferências para pesquisas futuras.

Contribuições: Por meio do Methodi Ordinatio, identificamos os artigos mais relevantes sobre o objeto de estudo. Analisandoos, nossa principal contribuição é um conjunto de diretrizes para futuras pesquisas sobre soft power em seis áreas: Psicossociologia, Mobilidade Laboral, Planejamento Urbano, Diplomacia Artística, Gastrodiplomacia e Indicações Geográficas.

Relevância e originalidade: até onde sabemos, o triângulo das indústrias criativas, place branding e soft power foi estudado apenas de forma delimitada, e este parece ser o primeiro artigo a vinculá-lo às áreas mencionadas.

Implicações gerenciais e sociais: Este triângulo não apenas contém desafios teóricos inexplorados, mas também apresenta áreas pouco observadas por profissionais e formuladores de políticas, o que pode provocar mais clareza para o planejamento da imagem de cidades, regiões e países. Não obstante a necessidade de mais estudos, as áreas que envolvem artes e gastronomia parecem ser iniciativas viáveis a curto prazo, enquanto as demais podem ser mais demoradas e custosas.

Palavras-chave: Soft power. Place branding. Indústria criativa. Economia criativa. Methodi Ordinatio.

\section{Como citar}

American Psychological Association (APA)

Campos, R. P., Galina, S. V. R., \& Giraldi, J. de. M. E. (2022, jan./mar.). Diretrizes para pesquisas futuras sobre soft power: uma abordagem oblíqua da literatura sobre o entrelaçamento entre indústrias criativas e marcas de lugar. Revista Brasileira de Marketing - ReMarK, 21(Num. Esp.), 114-141. https://doi.org/10.5585/remark.v21i1.20541. 


\section{Introdução}

Um dos cientistas mais renomados da história era consumido por um sentimento único. Os alemães o chamam de Fernweh. Mesmo jovem, Alexander von Humboldt sempre "sentiu uma inexplicável atração pelo desconhecido" (Wulf, 2015, p. 34, tradução nossa) talvez pelo fato de que, quando menino, ele "tinha lido os diários do capitão James Cook e Louis Antoine de Bougainville, ambos circunavegando o globo e se imaginado longe dali.” (Wulf, 2015, p. 32, tradução nossa).

Construído sobre as palavras longe (fern) e doloroso (weh), o termo descreve denotativamente uma saudade ou dor de viajar para outros países (Cambridge Dicionary, 2018, tradução nossa). Apesar de sua etimologia intrigante, a palavra é uma maneira popular de se referir a uma pessoa que sente saudade de um lugar que nunca esteve.

Pode-se concordar que esta significação é intrigante. De qualquer forma, este estudo não é uma tentativa de explorar esta palavra incomum. Este prólogo sobre a vida de Humboldt, no entanto, destaca como bens criativos podem gerar atração por diferentes lugares do mundo.

Cientificamente, existem, de maneira sucinta, dois ramos de conhecimento que dizem respeito à imagem e atração dos lugares. Soft power é um termo político para elucidar a capacidade que algumas nações têm de atrair e mover pessoas - não por meio de ameaças, coerção ou pagamentos - mas engajando o público internacional com a imagem de sua cultura, ideais políticos, e ações políticas (Nye, 2004). Paralelamente, estudiosos de marketing também têm tentado entender como as imagens de lugares são moldadas na mente das pessoas e como elas alteram seu comportamento em relação a esses lugares, classificando essa área como marca-país, marca de lugar ou marketing de lugar.

Em poucas palavras, soft power e marcas de lugar estão interligados, e não apenas entre si, mas também com as teorias e práticas das indústrias criativas - como os livros que Humboldt leu - pois criam globalmente imagens de lugares na mente das pessoas. Na pesquisa de soft power, essa imagem funciona como uma ilustração do desenvolvimento econômico, tecnológico, político e social de um lugar. Quanto à marca nacional, ela retrata seus produtos, inovação, status, confiabilidade e trabalho (Anholt, 2005; Maheshwari et al., 2019; Valaskivi, 2013).

Por um lado, sabe-se que "soft power e marca-país estão em relação direta um com o outro" (Kahraman, 2016, p. 95, tradução nossa), onde, "as iniciativas de marca-país podem servir como passos para a aquisição de soft power, aumentando a conscientização do público internacional sobre os elementos únicos de uma nação" (Rookwood, 2019, p. 31, tradução 
nossa). Por outro, no entanto, existem inúmeras publicações onde estes conceitos ainda são empregados de forma confusa e ambígua (Boisen et al., 2017; Fan, 2010; Hao et al., 2019; Skinner, 2008).

Postulamos que essa interdisciplinaridade não intencional pode levar a caminhos inexplorados nessas diferentes (ainda que complementares) áreas do conhecimento. Assim, o objetivo central deste trabalho é explorar este emaranhado conceitual como meio de desenvolver diretrizes para pesquisas futuras.

Para tanto, apresentamos uma revisão sistemática da literatura e análise de conteúdo de 39 textos publicados em periódicos indexados na base de dados Scopus. Primeiro, usamos o Methodi Ordinatio (Pagani et al., 2015) para encontrar, selecionar e classificar as publicações usando um conjunto de várias palavras-chave relacionadas.

Em seguida, averiguamos a frequência de ocorrência da palavra-chave ["soft power"], utilizando o software VOSviewer, em todos os textos, para verificar se os autores fizeram uso direto do termo.

Considerando que a maioria não o fez, analisamos o conteúdo de todos os textos para descobrir se eles se referem obliquamente à soft power - segundo Kay (2011), obliquidade é o processo de atingir objetivos complexos indiretamente. Em outras palavras, usamos a abordagem oblíqua para verificar se autores em marca-país podem estar fazendo alusões indiretas à soft power, o que nos permitiu descobrir é que a maioria dos autores tem o feito. Além disso, a partir dos resultados observamos que suas referências oblíquas contêm luzes peculiares para pesquisas futuras em seis áreas diferentes: Psicossociologia, Mobilidade Laboral, Planejamento Urbano, Diplomacia Artística, Gastrodiplomacia e Indicações Geográficas.

Como contribuição final, conjecturamos e apresentamos dois caminhos adicionais para pesquisas futuras: as interpretações equivocadas de place branding e a dinâmica de acesso à imagem do lugar por meio de produtos criativos e tradicionais, com ênfase em produtos falsificados.

\section{Referencial teórico}

O termo soft power foi cunhado pelo professor de Harvard Joseph Nye Jr. em 1990 para explorar o poder cultural, ideológico e atrativo dos Estados Unidos durante o período da Guerra Fria. 
A capacidade de estabelecer preferências tende a estar associada a recursos de poder intangíveis, como cultura, ideologia e instituições. Esta dimensão pode ser pensada como poder suave [soft power], em contraste com o poder duro [hard power] geralmente associado a recursos tangíveis, como força militar e econômica. (Nye, 1990, p. 45, tradução nossa).

Quase simultaneamente, em 1996, o conselheiro político independente Simon Anholt começou a escrever sobre nation branding [marca nacional] (Anholt, 2010). Embora o próprio autor tenha cunhado o termo, vale notar que ele acredita que "não existe isso de "nation branding'. [...] A ideia de que é possível 'fazer branding' para um país (ou para uma cidade ou região) da mesma forma que as empresas 'fazem branding' para seus produtos é vã e tola." (Anholt, 2010, p. 10, tradução nossa)

A marca de uma nação e seu soft power podem então ser entendidos como a soma total de suas percepções nas mentes dos stakeholders internacionais, como seu povo, lugar, cultura e idioma, história, comida, moda, rostos famosos, marcas globais e assim por diante (Fan, 2010). "Telenovelas latino-americanas, histórias em quadrinhos japonesas, filmes de kung fu de Hong Kong, música da África Ocidental, moda londrina, resorts turísticos balineses, vinhos australianos e cozinha mexicana" são exemplos de uma paleta cada vez maior de produtos culturais e criativos por meio dos quais os lugares são marcas e podem ficar internacionalmente conhecidos e admirados (Scott, 2004, p. 482, tradução nossa).

Na política, a atratividade da marca de uma nação é primordial. A atração cultural popular contribuiu para a vitória americana na Guerra Fria, por exemplo, visto que "a propaganda estatal soviética e os programas culturais não conseguiam acompanhar a influência da cultura popular comercial da América em flexibilidade ou atração.” (Nye, 2004, p. 49, tradução nossa)

Logo, os lugares querem aparecer na mente das pessoas de forma inovadora, criativa, interessante, autêntica e sedutora (Valaskivi, 2013), seja por motivos políticos ou econômicos. Mas, tendo em mente que as pessoas geralmente não têm experiências diretas em outros países, as percepções sobre diferentes nações são principalmente moldadas por sentimentos e hábitos, e não por informações e conhecimentos (Wang, 2013).

E é por isso que os produtos criativos e culturais são uma das pontes entre pessoas e lugares. Como diz Nye, "muito do soft power americano foi produzido por Hollywood, Harvard, Microsoft e Michael Jordan” (2004, p. 17, tradução nossa). E, hoje em dia, numa época em que as imagens de um país podem ser difundidas com mais facilidade e criatividade em todo o mundo, a corrida pelo soft power está mais acirrada do que nunca, e as 'potências' 
tradicionais, como Estados Unidos e França, têm que competir com 'recém-chegados', como China, Índia e Brasil (Marc, 2019).

Para Anholt (2010), marcas de lugares ou de países não são sobre comunicação, mas sobre políticas - como soft power. Na verdade, a marca da nação é um braço da comunicação da diplomacia pública para construir o soft power. A diferença é que, enquanto os estudos sobre diplomacia e soft power geralmente enfatizam a política, o nation branding foca na mudança econômica (Johnson, 2018).

De fato, os desafios sociais, políticos e metodológicos se sobrepõem quando se trata de marcas de lugar (Florek et al., 2021) e "sobre a maneira como os países e regiões entendem e gerenciam sua reputação externa e propósito interno" (Anholt, 2010, p. 111, tradução nossa).

Por um lado, a aplicação de branding para lugares é de grande interesse político (Mariutti \& Giraldi, 2021). O consumo de bens culturais e criativos pode associar os consumidores a uma identidade social particular e, em determinado momento, a uma tendência política precisa (Navarro, 2016), acabando por aumentar ou diminuir a atratividade e o soft power deste local. Além disso, a formulação de políticas administrativas também é fundamental para o posicionamento da marca, onde a participação contínua e eficiente das instituições governamentais é absolutamente necessária. Na prática, "como uma atividade financiada e gerenciada publicamente, desenvolver marcas de lugares requer legitimidade que só pode ser alcançada se seus resultados e impactos forem reconhecidos e compreendidos pelos gestores da cidade, comunidades, e outras partes interessadas" (Florek et al., 2021, p. 12, tradução nossa).

Cientificamente, a sobreposição conceitual entre place branding e soft power abrange mais do que política externa e interna - que, aliás, são um dos vértices do Hexágono da Marca Nacional (Anholt, 2005) e também explorados por Nye (2004) para falar sobre soft power. Ambas as áreas similarmente dissertam sobre cultura.

Inúmeros estudiosos entendem as marcas de lugar como fenômenos culturais complexos (Lucarelli \& Giovanardi, 2016), constituídos por sua interação com identidade e imagem (Pedeliento \& Kavaratzis, 2019). Quanto ao soft power, e "segundo as teorias das relações internacionais e da diplomacia internacional, as experiências dos indivíduos com produtos e serviços culturais podem ser vistas como uma forma de influência ideológica e cultural" (Rabêlo Neto et al., 2021, p. 2, tradução nossa).

Apesar de uma literatura volumosa, ainda há muito a ser entendido sobre soft power e nation branding simplesmente porque a atração é uma experiência subjetiva (Mattern, 2005), 
muitas vezes criada por indústrias criativas/culturais. Até onde sabemos, este triângulo de indústrias criativas, marcas de lugares e "poder suave" foi estudado apenas de forma restrita.

Lee (2021), por exemplo, examina a marca nacional da Coréia do Sul no filme Parasita, vencedor do Oscar de 2020, e como o fato potencializa o soft power e a diplomacia cultural do país. Marc (2019) narra como a cultura francesa e a música popular têm sido usadas para transmitir uma nova imagem da França, passando de um foco na cultura de elite para uma abordagem econômica, neoliberal, para ganhar influência internacional. Fung (2016) explora como a China implementou uma política cultural de marca nacional - tanto nacional quanto internacionalmente - como forma de impulsionar suas indústrias nacionais de música, cinema, animação e jogos online.

Em suma, parece que a atratividade das indústrias criativas pode estar direta ou indiretamente ligada aos conceitos de place branding e soft power, mesmo que parcialmente. Cultura e criatividade não são apenas valores centrais das marcas de lugares (DudekMańkowska \& Grochowski, 2019, p. 276), mas também são uma ferramenta política essencial para o poder de sucesso (Galeeva, 2020).

\section{Metodologia}

\subsection{Seleção e organização das publicações utilizando o Methodi Ordinatio}

O Methodi Ordinatio é uma metodologia de 9 etapas (Figura 1) proposta por Pagani et al. (2015) para buscar, selecionar e organizar estudos científicos relevantes, com base em três critérios: fator de impacto, ano de publicação, e número de citações. 


\section{Figura 1}

\section{Methodi Ordinatio}

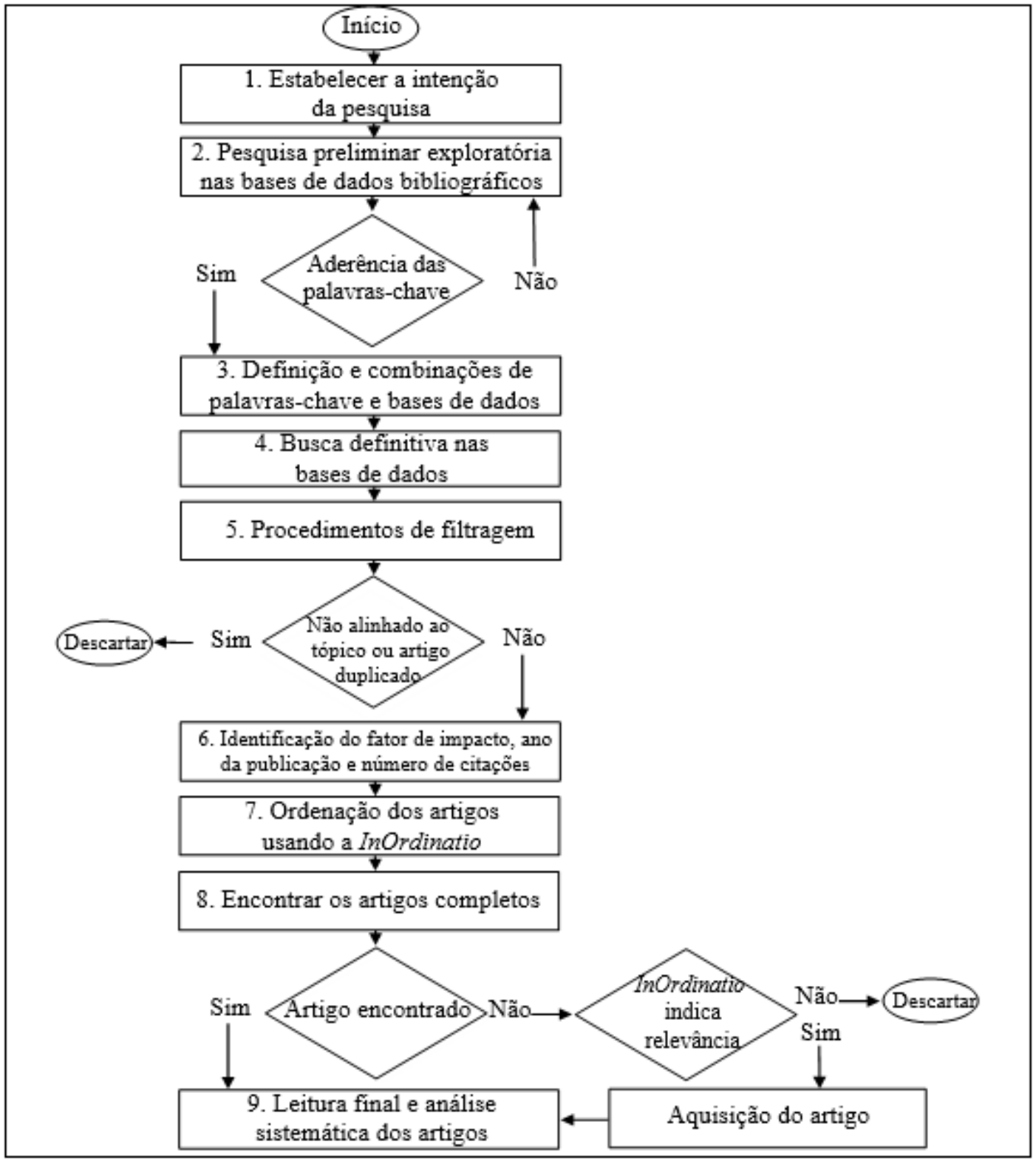

Fonte: Pagani et al. (2015, p. 2122).

Fase 1 - Estabelecer a intenção da pesquisa: O objetivo desta pesquisa é apresentar diretrizes para pesquisas futuras sobre soft power analisando seu entrelaçamento com dois ramos do conhecimento: indústrias criativas e marcas de lugar. Nossa intenção é explorar esta sobreposição conceitual em estudos relevantes como forma de encontrar novos caminhos interdisciplinares.

Fase 2 - Pesquisa preliminar exploratória nas bases de dados bibliográficos: a conhecida base de dados científicos Scopus da Elsevier foi utilizada, uma vez que contém uma 
visão abrangente da produção de pesquisa mundial. Primeiro selecionamos ["place branding"], ["creative economy"] como palavras-chave para uma consulta de abertura. O campo de pesquisa padrão TITLE-ABS-KEY (TÍTULO-RESUMO-PALAVRAS-CHAVE) foi usado.

Fase 3 - Definição e combinações de palavras-chave e bases de dados: Os estudos resultantes da fase anterior nos levaram a um conjunto mais amplo e robusto de palavras-chave, conforme mostrado na Figura 2, que representa o conjunto final de palavras-chave a ser explorado.

Fase 4 - Busca definitiva nas bases de dados com gerenciador de referências: Foram realizadas 20 buscas documentais com as palavras-chave entrelaçadas, conforme demonstrado na Figura 2. Elas resultaram em 49 artigos. Livros e capítulos de livros são impraticáveis para a equação InOrdinatio por não possuírem uma medida de fator de impacto, e, portanto, não são considerados aqui.

\section{Figura 2}

Palavras-chave relacionadas a indústrias criativas e marcas de lugar

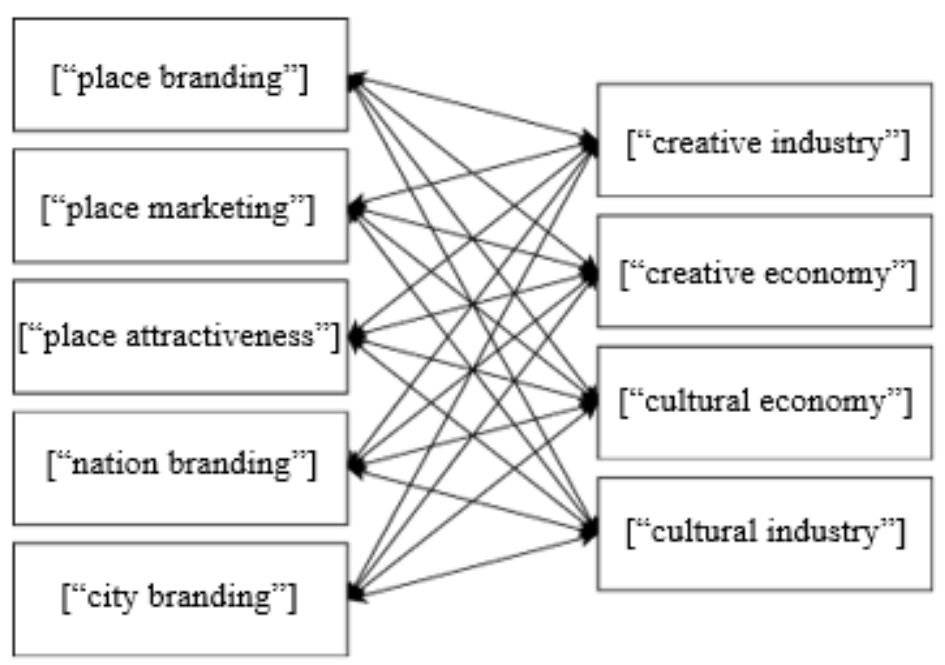

Fonte: Elaborado pelos autores.

Fase 5 - Procedimentos de filtragem: Os artigos resultantes foram organizados usando gerenciadores de referências, conforme recomendação dos autores do Methodi Ordinatio. O Mendeley é um software livre e rede social fornecido pela editora acadêmica Elsevier, e o JabRef é também uma plataforma de código aberto, usada para coletar, editar, organizar e citar trabalhos acadêmicos. Usamos o Mendeley para exportar os artigos da base de dados Scopus, realizar procedimentos de filtragem, e encontrar trabalhos duplicados - dos primeiros 49 
artigos, 10 eram duplicados, resultando em 39 artigos. O JabRef foi então usado para organizar mais facilmente os artigos resultantes, em tabelas.

Fase 6 - Identificação do fator de impacto, ano de publicação e número de citações: $\mathrm{O}$ ano de publicação está disponível para cada artigo após exportá-los para os gerenciadores de referências, mas o fator de impacto de cada revista de publicação e o número de citações de cada artigo tiveram que ser obtidos de duas outras fontes. $\mathrm{O}$ fator de impacto foi extraído do The SCImago Journal \& Country Rank, um portal disponível publicamente para indicadores científicos contidos na base de dados Scopus. O número de citações foi coletado da plataforma Google Acadêmico.

Fase 7 - Ordenação dos artigos usando a InOrdinatio: A equação InOrdinatio é aplicada para classificar os trabalhos de acordo com sua relevância: quanto maior o valor obtido, mais relevante o trabalho. Os artigos resultantes são classificados e apresentados na Tabela 1.

InOrdinatio $=\left(\frac{I F}{1000}\right)+\alpha *\left[10-(\right.$ AnoDaPesquisa - AnoDePublicação $]+\left(\sum C i\right)$, onde

- IF é o fator de impacto do periódico (dividido por 1000 para normalização).

- $\alpha$ é um fator de ponderação (peso). Varia de 1 a 10 para representar a opinião do pesquisador sobre a relevância do ano critério - considerando que a publicação mais antiga data de 2004, estabelecemos o fator de ponderação $\alpha$ como 10, conforme sugerido pelos autores para temas relativamente novos.

- $C i$ é o número de vezes que o artigo foi citado.

\section{Tabela 1}

Artigos resultantes do Methodi Ordinatio

\begin{tabular}{|c|c|c|c|c|c|c|}
\hline $\mathbf{N}^{0}$. & Autoria & $\begin{array}{l}\text { Título (originalmente em inglês, } \\
\text { aqui em tradução nossa) }\end{array}$ & InOrdinatio & Ano & $\mathbf{F i}$ & $\mathbf{C i}$ \\
\hline 1 & Scott (2004) & $\begin{array}{l}\text { Indústrias de produtos culturais e } \\
\text { desenvolvimento econômico urbano: } \\
\text { Perspectivas de crescimento e contestação de } \\
\text { mercado no contexto global }\end{array}$ & 694,00 & 2004 & 1,189 & 754 \\
\hline 2 & $\begin{array}{l}\text { Currid \& Williams } \\
(2010)\end{array}$ & $\begin{array}{l}\text { A geografia do buzz: arte, cultura e o meio } \\
\text { social em Los Angeles e Nova York }\end{array}$ & 178,00 & 2010 & 2,192 & 178 \\
\hline 3 & Lee et al. (2015) & $\begin{array}{l}\text { Clusters de alimentos criativos e } \\
\text { desenvolvimento rural por meio da marca } \\
\text { local: iniciativas de turismo culinário em } \\
\text { Stratford e Muskoka, Ontário, Canadá }\end{array}$ & 144,00 & 2015 & 1,624 & 94 \\
\hline
\end{tabular}




\begin{tabular}{|c|c|c|c|c|c|c|}
\hline $\mathbf{N}^{0}$. & Autoria & $\begin{array}{l}\text { Título (originalmente em inglês, } \\
\text { aqui em tradução nossa) }\end{array}$ & InOrdinatio & Ano & $\mathbf{F i}$ & $\mathbf{C i}$ \\
\hline 4 & Valaskivi (2013) & $\begin{array}{l}\text { Um novo futuro? Cool Japan e o imaginário } \\
\text { social da nação de marca }\end{array}$ & 131,00 & 2013 & 0,259 & 101 \\
\hline 5 & Jones (2009) & $\begin{array}{l}\text { Colocando a arquitetura em seu lugar social: } \\
\text { uma economia político-cultural da arquitetura }\end{array}$ & 117,00 & 2009 & 1,618 & 127 \\
\hline 6 & Lange et al. (2008) & $\begin{array}{l}\text { As indústrias criativas de Berlim: } \\
\text { Governando a criatividade? }\end{array}$ & 107,00 & 2008 & 1,738 & 127 \\
\hline 7 & $\begin{array}{l}\text { Ulldemolins \& } \\
\text { Zamorano (2015) }\end{array}$ & $\begin{array}{l}\text { O projeto de marca nacional da Espanha } \\
\text { Marca España e sua política cultural: a } \\
\text { instrumentalização econômica e política de } \\
\text { uma imagem cultural homogênea e } \\
\text { simplificada }\end{array}$ & 104,00 & 2015 & 0,607 & 54 \\
\hline 8 & Cudny et al. (2020) & $\begin{array}{l}\text { Artes e criatividade: uma estratégia de } \\
\text { negócios e branding para Lodz como cidade } \\
\text { neoliberal }\end{array}$ & 102,00 & 2020 & 1,606 & 2 \\
\hline 9 & Oh (2020) & $\begin{array}{l}\text { Das paredes de concreto às paredes digitais: } \\
\text { construção transmídia do mito do lugar em } \\
\text { Ihwa Mural Village, Coreia do Sul }\end{array}$ & 101,00 & 2020 & 1,349 & 1 \\
\hline 10 & Jacobsen (2012) & $\begin{array}{l}\text { Valor da marca de lugar: um modelo para } \\
\text { estabelecer a eficácia das marcas locais }\end{array}$ & 100,00 & 2012 & 0,598 & 80 \\
\hline 11 & Moreno (2020) & $\begin{array}{l}\text { Histórias de cidades sustentáveis: o } \\
\text { patrimônio cultural como recurso para um } \\
\text { desenvolvimento urbano mais verde e justo }\end{array}$ & 100,00 & 2020 & 0,283 & 0 \\
\hline 12 & $\begin{array}{l}\text { Askegaard \& } \\
\text { Kjeldgaard (2007) }\end{array}$ & $\begin{array}{l}\text { Aqui, ali, e em todo lugar: marcas de lugares } \\
\text { e a globalização gastronômica em uma } \\
\text { perspectiva de macromarketing }\end{array}$ & 99,00 & 2007 & 0,736 & 129 \\
\hline 13 & $\begin{array}{l}\text { Warren \& Dinnie } \\
\text { (2018) }\end{array}$ & $\begin{array}{l}\text { Intermediários culturais em marcas de lugar: } \\
\text { quem são e como constroem legitimidade } \\
\text { para seu trabalho e para si mesmos? }\end{array}$ & 97,00 & 2018 & 3,068 & 17 \\
\hline 14 & Hristova (2019) & $\begin{array}{l}\text { A arquitetura como fator de sustentabilidade } \\
\text { cultural das cidades macedônias: o branding } \\
\text { de Bitola }\end{array}$ & 94,00 & 2019 & 0,997 & 4 \\
\hline 15 & Farhat (2019) & $\begin{array}{l}\text { Que marca é este lugar? Criação de lugares e } \\
\text { a política cultural da revitalização do centro }\end{array}$ & 94,00 & 2019 & 0,466 & 4 \\
\hline 16 & Listerborn (2017) & $\begin{array}{l}\text { O conceito emblemático do ' } 4^{\circ} \text { ambiente } \\
\text { urbano'. Branding e visão em Malmö, Suécia }\end{array}$ & 93,00 & 2017 & 1,035 & 23 \\
\hline 17 & $\begin{array}{l}\text { Maheshwari et al. } \\
\text { (2019) }\end{array}$ & $\begin{array}{l}\text { Investigando as atitudes dos moradores dos } \\
\text { Jogos Olímpicos de 2016: Examinando as } \\
\text { dimensões socioculturais, econômicas e } \\
\text { ambientais }\end{array}$ & 92,00 & 2019 & 0,236 & 2 \\
\hline 18 & $\begin{array}{l}\text { Dudek- } \\
\text { Mańkowska \& } \\
\text { Grochowski (2019) }\end{array}$ & $\begin{array}{l}\text { Das indústrias criativas à marcas de lugares } \\
\text { criativos: algumas reflexões sobre marcas de } \\
\text { cidades na Polônia }\end{array}$ & 91,00 & 2019 & 0,279 & 1 \\
\hline 19 & $\begin{array}{l}\text { Scott \& Szili } \\
(2018)\end{array}$ & $\begin{array}{l}\text { Pop-up Polanyi: Empreendedores culturais e } \\
\text { a "correção de vagas" }\end{array}$ & 87,00 & 2018 & 0,736 & 7 \\
\hline 20 & Chow (2017) & $\begin{array}{l}\text { Explorando a mobilidade da classe criativa: } \\
\text { trabalhadores criativos de Hong Kong em } \\
\text { Xangai e Pequim }\end{array}$ & 87,00 & 2017 & 1,09 & 17 \\
\hline 21 & Molnár (2018) & $\begin{array}{l}\text { O negócio do urbano "descolado": mercados } \\
\text { emergentes para arte de rua }\end{array}$ & 82,00 & 2018 & 1,172 & 2 \\
\hline 22 & $\begin{array}{l}\text { Loftsdóttir et al. } \\
\text { (2017) }\end{array}$ & $\begin{array}{l}\text { Presos em clichês: masculinidade, cinema e } \\
\text { turismo na Islândia }\end{array}$ & 81,00 & 2017 & 1,024 & 11 \\
\hline 23 & Fung (2016) & $\begin{array}{l}\text { Estratégias para indústrias criativas na China: } \\
\text { contradições e tensão na marca nacional }\end{array}$ & 78,00 & 2016 & 0,927 & 18 \\
\hline 24 & Navarro (2016) & $\begin{array}{l}\text { Indústrias criativas e Britpop: a } \\
\text { mercantilização da cultura, política e } \\
\text { identidade nacional }\end{array}$ & 75,00 & 2015 & 0,904 & 15 \\
\hline
\end{tabular}




\begin{tabular}{|c|c|c|c|c|c|c|}
\hline $\mathbf{N}^{0}$. & Autoria & $\begin{array}{l}\text { Título (originalmente em inglês, } \\
\text { aqui em tradução nossa) }\end{array}$ & InOrdinatio & Ano & $\mathbf{F i}$ & $\mathbf{C i}$ \\
\hline 25 & $\begin{array}{l}\text { Oliveira \& Padilla } \\
(2017)\end{array}$ & $\begin{array}{l}\text { Integrando a superdiversidade na governação } \\
\text { urbana: O caso do centro da cidade de Lisboa }\end{array}$ & 74,00 & 2017 & 1,507 & 4 \\
\hline 26 & Romão (2017) & $\begin{array}{l}\text { As cidades criativas são bons lugares para } \\
\text { pessoas criativas? Notas sobre as condições } \\
\text { sociais para a produção cultural na economia } \\
\text { contemporânea }\end{array}$ & 74,00 & 2017 & 0,197 & 4 \\
\hline 27 & Marsh (2016) & $\begin{array}{l}\text { Branding do Brasil por meio da política } \\
\text { cultural: o Rio de Janeiro como cidade } \\
\text { criativa e audiovisual }\end{array}$ & 71,00 & 2016 & 0,927 & 11 \\
\hline 28 & $\begin{array}{l}\text { Jelinčić \& Vukić } \\
\text { (2015) }\end{array}$ & $\begin{array}{l}\text { Indústrias criativas como portadoras da } \\
\text { identidade urbana e impulsionadoras do } \\
\text { desenvolvimento: do branding direcional ao } \\
\text { participativo }\end{array}$ & 56,00 & 2015 & 0,391 & 6 \\
\hline 29 & Yue (2006) & $\begin{array}{l}\text { Governança cultural e indústrias criativas em } \\
\text { Cingapura }\end{array}$ & 45,00 & 2006 & 0,607 & 85 \\
\hline 30 & Allon (2013) & Fantasmas da cidade aberta & 44,00 & 2013 & 0,466 & 14 \\
\hline 31 & Cudny (2014) & $\begin{array}{l}\text { A influência da série de TV Komisarz Alex } \\
\text { no desenvolvimento de Lodz (Polônia) aos } \\
\text { olhos dos habitantes da cidade }\end{array}$ & 43,00 & 2014 & 0,693 & 3 \\
\hline 32 & Maher et al. (2013) & $\begin{array}{l}\text { Medidas políticas para a criação de um } \\
\text { sistema de inovação integrado e focado na } \\
\text { marca para indústrias cinematográficas em } \\
\text { nações sombrias: uma aplicação na indústria } \\
\text { cinematográfica nacional da Austrália }\end{array}$ & 34,00 & 2013 & 0,2 & 4 \\
\hline 33 & $\begin{array}{l}\text { Karachalis \& } \\
\text { Deffner (2012) }\end{array}$ & $\begin{array}{l}\text { Repensando a conexão entre clusters criativos } \\
\text { e marcas de cidade: o eixo cultural da Rua } \\
\text { Piraeus em Atenas }\end{array}$ & 29,00 & 2012 & 0,257 & 9 \\
\hline 34 & McElroy (2011) & $\begin{array}{l}\text { Colocando o marco de volta na televisão: } \\
\text { produzindo valores de lugar e de cultura em } \\
\text { Cardiff }\end{array}$ & 22,00 & 2011 & 0,279 & 12 \\
\hline 35 & Yessenova (2011) & $\begin{array}{l}\text { Nômade para exportação, não para consumo } \\
\text { interno: o esforço emperrado do Cazaquistão } \\
\text { para 'colocar o país no mapa' }\end{array}$ & 20,00 & 2011 & 0,101 & 10 \\
\hline 36 & Jacobsen (2010) & $\begin{array}{l}\text { Marcas de lugares urbanos e a localização de } \\
\text { indústrias criativas: um modelo para medir o } \\
\text { valor da marca de lugares }\end{array}$ & 9,00 & 2010 & 0,527 & 9 \\
\hline 37 & Brabazon (2009) & $\begin{array}{l}\text { Branding em Wellington: Quando a imagem } \\
\text { da cidade é "GLAMurosa": uma visão pessoal }\end{array}$ & 2,00 & 2009 & 0,279 & 12 \\
\hline 38 & Liu \& Ko (2010) & $\begin{array}{l}\text { Uma cidade local para uma cidade criativa: } \\
\text { um exame de Taichung, Taiwan }\end{array}$ & 2,00 & 2010 & 0,17 & 2 \\
\hline 39 & $\begin{array}{l}\text { Lange \& Stöber } \\
(2008)\end{array}$ & $\begin{array}{l}\text { "A cidade é a estrela": Comparações dos } \\
\text { processos de criação de lugares através das } \\
\text { indústrias criativas em Berlim e Copenhague }\end{array}$ & $-17,00$ & 2008 & 0,17 & 3 \\
\hline
\end{tabular}

Fonte: Elaborado pelos autores.

\section{A Fase 8 (Encontrar os artigos completos) e a Fase 9 (Leitura final e análise sistemática}

dos artigos) são tarefas simples e objetivas. Elas são o fim do Methodi Ordinatio, mas o início de nossa análise de conteúdo. 


\subsection{Análise de conteúdo e abordagem oblíqua}

As análises de conteúdo reduzem "a complexidade de uma coleção de textos" e “envolvem a contagem e comparações, geralmente de palavras-chave ou conteúdo, seguidas da interpretação do contexto implícito" (Bauer, 2000, p. 132; Hsieh \& Shannon, 2005, p. 1277, tradução nossa). Como Braun e Clarke (2012, p. 61, tradução nossa) sugerem: riqueza "pode ser encontrada até mesmo em breves extratos de texto".

Nossa análise de conteúdo foi construída em três etapas. Primeiramente, analisamos a coocorrência de palavras-chave usando o VOSviewer (Figura 3), desenvolvido por van Eck \& Waltman (2010).

\section{Figura 3}

\section{Mapa VOSviewer de Coocorrência de Palavras-Chave}

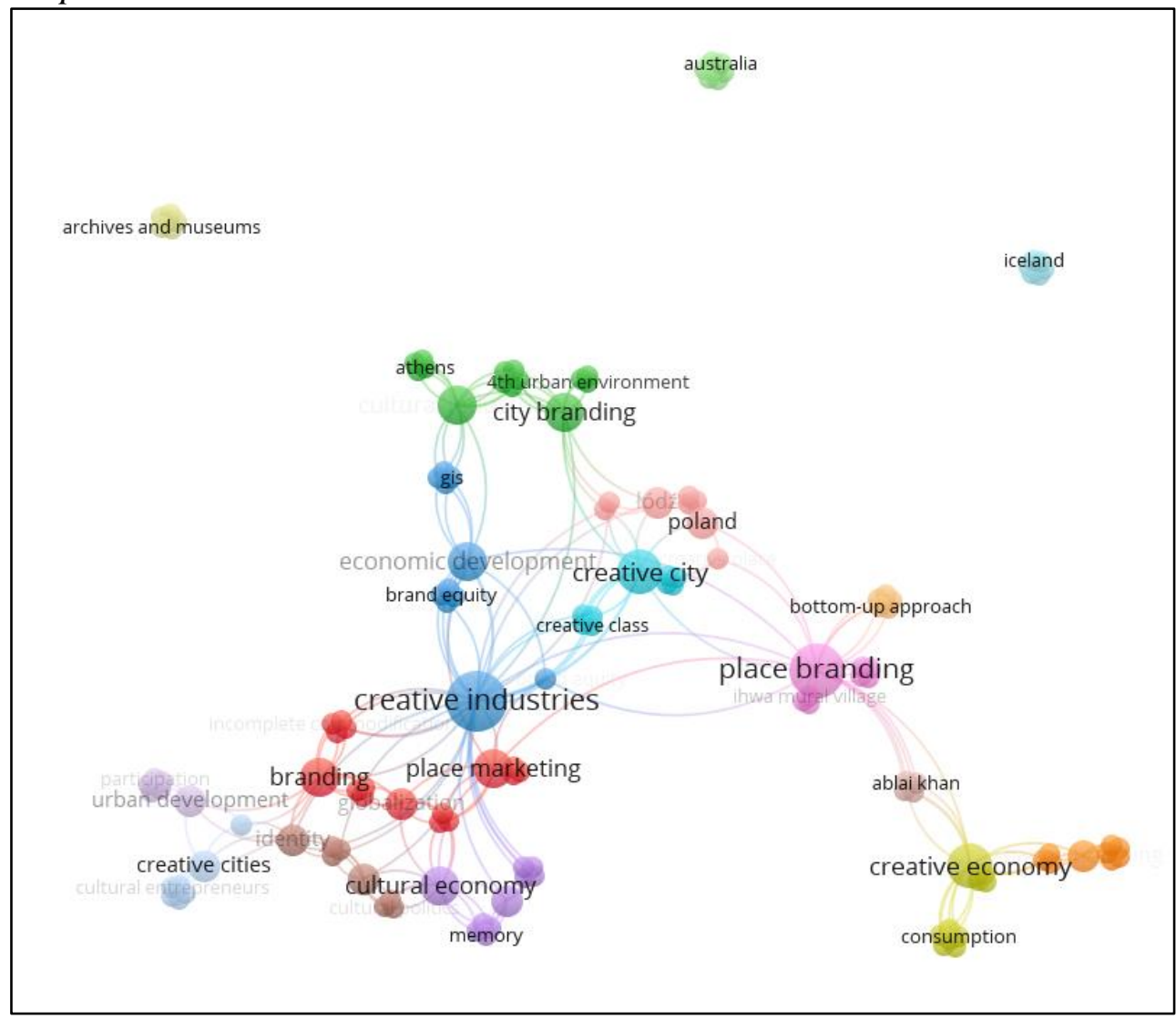

Fonte: Elaborado pelos autores.

Em segundo lugar, contamos o uso do termo soft power em cada publicação para saber se os autores fazem uso dele. E, em terceiro lugar, analisamos o conteúdo de cada artigo, 
buscando usos oblíquos do soft power (Tabela 2). Por oblíquo, queremos dizer indireto, não explícito.

Vale ressaltar que, metodologicamente, Kay (2011) entende a obliquidade como um processo de experimentação e descoberta para atingir objetivos de forma indireta. Nessa perspectiva, pode-se dizer que as ideias por trás dos estudos de place branding e de soft power são um tanto oblíquas, uma vez que suas relações conceituais não são diretas - e, segundo Rookwood (2019) - ainda estão em processo de formulação, tanto por praticantes quanto por estudiosos.

De qualquer forma, o que Kay (2011) chama de "abordagem oblíqua" parece ser um método interessante para os objetivos desta pesquisa, pois leva em conta a sutileza e a riqueza de conteúdos complexos.

\section{Tabela 2}

\section{Análise de Conteúdo com Abordagem Oblíqua dos Artigos Resultantes}

\section{Uso do \\ $N^{o}$. termo "soft \\ Excertos textuais que se referem direta ou indiretamente à soft power power"}

"Um objetivo [dos programas da indústria do patrimônio, que administra locais históricos, prédios e museus] é atrair um número maior de visitantes de outras áreas. Outro objetivo, e

10 possivelmente ainda mais importante, é melhorar a imagem e o prestígio de determinados lugares, de modo a atrair investidores de alto nível e os trabalhadores qualificados e com altos salários que os seguem." (Scott, 2004, p. 464, tradução nossa)

"Modelos contemporâneos de desenvolvimento argumentam que, para atrair pessoas, as

20 cidades devem cultivar lugares (e imagens desses lugares) que ofereçam as qualidades que as pessoas desejam em um lugar para viver e trabalharor (Veja Brooks, 2000; Glaeser et al., 2000; Florida, 2002; Clark, 2004).” (Currid \& Williams, 2010, p. 427, tradução nossa)

"Assim, 'terroir' é um conceito que reconhece um 'senso de lugar' que [...] pode estar ligado às características criativas e artísticas do lugar, e são intrínsecas à identidade e imagem do lugar (Lee e Wall, 2014). Assim, um terroir é um lugar bem definido e altamente 30 especializado, com características culturais distintas e produtos associados (Croce e Perri, 2010). Moradores e visitantes são atraídos por esses lugares que estabeleceram uma paisagem cultural e artística única que pode ser usada para criar uma identidade e imagem de lugar distintas." (Lee et al., 2015, p. 135, tradução nossa)

"Seguindo essa tendência, os políticos japoneses começaram a circular a ideia de criar soft 44 power por meio do fenômeno Cool Japan. Declarações e discursos tornaram-se documentos de estratégia, medidas e decisões de financiamento, e animes e mangás começaram a ser usados na diplomacia cultural.” (Valaskivi, 2013, p. 488, tradução nossa)

"A CPE [Economia Política Cultural - da arquitetura] buscaria posicionar esses edifícios em relação ao 'imaginário econômico' (Jessop, 2004) da regeneração liderada pela cultura, que

50 fez uso extensivo dos elementos ostensivamente 'soft' do capitalismo - baseado em informação, criatividade, conhecimento e objetos culturais (Thrift, 1998; Sayer, 1999, 2001) - para 'vender cidades' para turistas e investidores como desejáveis (Hall e Hubbard, 1998)". (Jones, 2009, p. 2532, tradução nossa).

"Em primeiro lugar, e isso é importante para os profissionais de marketing da cidade, gerentes e outros profissionais urbanos não apenas em Berlim, mas em todo o mundo, 'o lugar importa' - novamente. Nossas cidades, como já mencionado acima, não são intercambiáveis, mas possuem características particulares que, quando identificadas e influenciadas 


\begin{tabular}{|c|c|c|}
\hline $\mathbf{N}^{\mathbf{0}}$. & $\begin{array}{l}\text { Uso do } \\
\text { termo "soft } \\
\text { power" }\end{array}$ & Excertos textuais que se referem direta ou indiretamente à soft power \\
\hline & & $\begin{array}{l}\text { adequadamente, podem ajudá-las a se posicionar internacionalmente, criar distinção e } \\
\text { vantagem competitiva na suposta concorrência internacional.” (Lange et al., 2008, p. 538, } \\
\text { tradução nossa) }\end{array}$ \\
\hline 7 & 2 & $\begin{array}{l}\text { "A diplomacia cultural está sendo cada vez mais considerada o meio no qual os Estados- } \\
\text { nação podem instrumentalizar sua produção cultural e alcançar objetivos de soft power. } \\
\text { Analistas sublinharam repetidamente a importância da cultura no place branding das } \\
\text { economias globalizadas, onde a cultura pode singularizar os produtos e atribuir-lhes maior } \\
\text { valor." (Ulldemolins \& Zamorano, } 2015 \text {, p. } 20 \text {, tradução nossa) }\end{array}$ \\
\hline 8 & 0 & $\begin{array}{l}\text { "As cidades investem em desenvolvimento cultural, artes, indústrias criativas, festivais e } \\
\text { outros eventos para desenvolver um leque de oportunidades e como uma estratégia geral para } \\
\text { se engajar na competição urbana global, comportando-se como empresas que tentam se } \\
\text { diferenciar no mercado, investindo em criatividade e patrocinando eventos artísticos".(Cudny } \\
\text { et al., } 2020 \text {, p. 1, tradução nossa) }\end{array}$ \\
\hline 9 & 0 & $\begin{array}{l}\text { "Quando mais imagens de murais são representadas e (re)produzidas através de diversas } \\
\text { formas de mídia, isso gera um forte poder de marca para um local como 'o melhor local para } \\
\text { fotos', enquanto tal proliferação de imagens acelera o distanciamento da representação das } \\
\text { realidades socioeconômicas no lugar." (Oh, 2020, p. 2, tradução nossa) }\end{array}$ \\
\hline 10 & 0 & - \\
\hline 11 & 0 & $\begin{array}{l}\text { "O planejamento urbano tem o poder de moldar os pensamentos, emoções e ações de seus } \\
\text { habitantes (Gallagher, 1993). A vida urbana mostra os dois lados: o escuro como lugares } \\
\text { cheios de obstáculos: caros, insalubres, perigosos, exclusivos e anônimos. O brilhante, do } \\
\text { fascínio, da atração, do encontro social, da colaboração, da solidariedade; o lugar que } \\
\text { proporciona conhecimento, ideias, informação, liberdade, entretenimento, emancipação. } \\
\text { Enfrentar os desafios e aproveitar as vantagens é o caminho que leva ao objetivo principal de } \\
\text { um futuro urbano melhor: a sustentabilidade." (Rivero Moreno, 2020, p. 400, tradução). }\end{array}$ \\
\hline 12 & 0 & $\begin{array}{l}\text { "Para a população de Funen, a produção e comercialização de produtos locais de particular } \\
\text { qualidade gastronômica é potencialmente uma fonte de saúde, estilos de vida renovados e } \\
\text { renda. Os benefícios econômicos não estão vinculados apenas à comercialização e venda dos } \\
\text { produtos. Estão também ligados aos lucros derivados do turismo, à atração de novos cidadãos } \\
\text { de outras partes do país pela melhoria da qualidade de vida, e aos efeitos derivados em termos } \\
\text { de conferências, centros de aprendizagem e atratividade de investimentos relacionados à } \\
\text { torná-los um 'centro de excelência"'. (Askegaard \& Kjeldgaard, 2007, p. 146, tradução nossa) }\end{array}$ \\
\hline 13 & 0 & $\begin{array}{l}\text { "Se entendermos que os profissionais de marketing, por meio de sua posição no centro da } \\
\text { representação cultural, criam identidades específicas que representam certas formas de ver a } \\
\text { realidade e têm certo grau de poder sobre como a realidade é percebida pelo público-alvo, } \\
\text { podemos inferir que essas identidades podem refletir e reforçar percepções que são } \\
\text { fundamentadas em estruturas de poder hegemônicas particulares.' (Morgan \& Pritchard, } \\
\text { 1998)." (Warren \& Dinnie, 2018, p. 304, tradução nossa) }\end{array}$ \\
\hline 14 & 0 & $\begin{array}{l}\text { "Para dar suporte às imagens dos lugares que procuramos projetar no mapa cultural global, } \\
\text { precisamos de uma compreensão mais profunda do papel das indústrias criativas no âmbito } \\
\text { da estratégia cultural nacional para o desenvolvimento sustentável. A abertura da plataforma } \\
\text { cultural de cidades criativas é apenas um dos segmentos que podem levar a um } \\
\text { reconhecimento mais amplo das indústrias criativas como fatores de desenvolvimento } \\
\text { econômico, onde a arquitetura também pode expressar seus múltiplos talentos e } \\
\text { competências." (Hristova, } 2019 \text {, p. } 235 \text {, tradução nossa) }\end{array}$ \\
\hline 15 & 0 & $\begin{array}{l}\text { "À medida que as cidades continuam a reinventar suas economias pós-industriais, o branding } \\
\text { constitui uma estratégia "soft" [suave] para atualizar esse programa (Hubbard, 1996; Lash \& } \\
\text { Urry, 1994; Short, Benton, Luce e Walton, 1993)." (Farhat, 2019, p. 2, tradução nossa). [...] } \\
\text { "Hoje, as estratégias suaves tornaram-se centrais para criar comunidades culturais e estimular } \\
\text { a atividade econômica. Consequentemente, o planejamento da regeneração urbana em torno } \\
\text { das artes e do entretenimento ganhou popularidade." (Farhat, 2019, p. 12, tradução nossa). }\end{array}$ \\
\hline 16 & 0 & $\begin{array}{l}\text { "O poder da imaginação urbana está em seu potencial de ser institucionalizado no } \\
\text { planejamento e em sua capacidade de viajar translocalmente. A cidade de Malmö está } \\
\text { tentando se comercializar como produtora de conceitos de planejamento e usar a plataforma } \\
\text { da Nordic City Network para promovê-la, que é um laboratório de ideias de planejadores }\end{array}$ \\
\hline
\end{tabular}




\begin{tabular}{|c|c|c|}
\hline $\mathbf{N}^{\mathbf{0}}$. & $\begin{array}{l}\text { Uso do } \\
\text { termo "soft } \\
\text { power" }\end{array}$ & Excertos textuais que se referem direta ou indiretamente à soft power \\
\hline & & $\begin{array}{l}\text { urbanos e regionais dedicados ao desenvolvimento de cidades nórdicas como atraentes, } \\
\text { inovadoras, e cidades de conhecimento competitivo." (Listerborn, 2017, p. 25). }\end{array}$ \\
\hline 17 & 0 & $\begin{array}{l}\text { "A Copa do Mundo FIFA de } 2010 \text { foi considerada uma oportunidade para a África do Sul } \\
\text { reduzir a pobreza, apoiando campanhas de melhoria das condições de vida dos historicamente } \\
\text { desfavorecidos e redesenhar as cidades do apartheid (Pillay e Bass, 2008). Além disso, os } \\
\text { Jogos Olímpicos de Pequim } 2008 \text { foram vistos pela maioria como uma forma de diminuir a } \\
\text { distância cultural entre a China e o mundo exterior (Zhou e Ap, 2009). Os Jogos Olímpicos } \\
\text { de Londres } 2012 \text { trouxeram vários impactos sociais positivos, como vida sustentável, respeito } \\
\text { e igualdade e, consequentemente, proporcionaram melhores oportunidades para os moradores } \\
\text { e comunidades em geral." (Maheshwari et al., 2019, p. 295, tradução nossa) }\end{array}$ \\
\hline 18 & 0 & $\begin{array}{l}\text { "O poder de atração dessas cidades varia. A força de Varsóvia - a capital da Polônia - é } \\
\text { demonstrada pela localização de quase } 37 \% \text { das empresas criativas registradas em todas as } \\
\text { cidades - capitais das regiões polonesas." (Dudek-Mańkowska \& Grochowski, 2019, p. 285, } \\
\text { tradução nossa) }\end{array}$ \\
\hline 19 & 0 & $\begin{array}{l}\text { "Como Lash e Urry (1994, p. 326) notaram, a cidade é: ... refeita ou reimaginada, muitas } \\
\text { vezes para atrair fluxos de turistas ou empreendedores .... O que é distinto sobre o refazer } \\
\text { contemporâneo do lugar são os seguintes: a importância da imagem e, especialmente, a } \\
\text { reflexividade (estética) do lugar. [...] Uma vez facilitado no espaço urbano, o trabalho afetivo } \\
\text { e material dos empreendedores culturais é reunido com as estratégias estaduais de turismo, } \\
\text { para atrair viajantes nacionais e internacionais (ver South Australian Government, 2017b)." } \\
\text { (M. Scott \& Szili, } 2018, \text { p. 4, tradução nossa). }\end{array}$ \\
\hline 20 & 0 & $\begin{array}{l}\text { "Mapeando o campo de estudos sobre mobilidade criativa de classe, Kong [Lily Kong, 2014] } \\
\text { cita uma série de investigações transnacionais que testam a validade do acoplamento teórico } \\
\text { de um lugar animado, moderno, e movimentado e o desejo de se mudar para lá, ou o seu outro } \\
\text { lado, quando um lugar perde sua atratividade e a força de trabalho criativa sai. Existem } \\
\text { estudos que fornecem evidências confirmatórias, mas muitas vezes complexas. Em seu } \\
\text { estudo sobre a classe criativa de Dublin, por exemplo, Bennett et al. (2009) constatam que os } \\
\text { fatores "soft" desempenham um papel importante, mas apenas para uma pequena minoria, na } \\
\text { decisão de onde trabalhar." (Chow, } 2017 \text {, p. } 5 \text {, tradução nossa) }\end{array}$ \\
\hline 21 & 0 & - \\
\hline 22 & 0 & $\begin{array}{l}\text { "Waade e Jensen (2013) concluem que um dos objetivos conscientes de destacar os temas } \\
\text { associados ao noir nórdico é ganhar preços internacionais para facilitar a possibilidade de } \\
\text { atrair mais financiamento do exterior, lembrando-nos, assim, que as preocupações artísticas } \\
\text { e econômicas não estão, necessariamente, separadas uma da outra." (Loftsdóttir et al., 2017, } \\
\text { pp. 1237-1238, tradução nossa) }\end{array}$ \\
\hline 23 & 13 & $\begin{array}{l}\text { "Como este artigo demonstra, o soft power também tem uma dimensão interna. O soft power } \\
\text { não é uma exibição internacional da imagem da China através de riqueza ou política, mas é } \\
\text { uma espécie de poder "capilar" que gera um discurso de "feito na China" que pode penetrar } \\
\text { na nova geração (Foucault, 1980). Por meio de suas indústrias culturais, o Estado pode } \\
\text { estabilizar a política interna e as condições sociais." (Fung, 2016, p. 3017, tradução nossa). }\end{array}$ \\
\hline 24 & 0 & $\begin{array}{l}\text { "Para encerrar, este estudo sugere que o consumismo juvenil e a cultura popular são utilizados } \\
\text { como uma força motriz econômica e política crucial em favor de interesses partidários ou } \\
\text { governamentais, politizando hábitos de consumo e mercantilizando produtos culturais. Além } \\
\text { disso, os governos parecem responsáveis por moldar o impacto eventual de alguns } \\
\text { movimentos culturais de sucesso, provando assim sua capacidade de modelar a cultura e } \\
\text { controlar as tendências sociais." (Navarro, 2016, p. 3, tradução nossa) }\end{array}$ \\
\hline 25 & 0 & - \\
\hline 26 & 0 & $\begin{array}{l}\text { "Em um mundo globalizado, a crescente competição pela atratividade de mão de obra } \\
\text { qualificada, empresas eficientes e fluxos de investimentos também reforça o papel da } \\
\text { governança e das instituições públicas, visando a conquista de novas formas de vantagem } \\
\text { competitiva decorrentes da produção e disseminação de conhecimento e criatividade." } \\
\text { (Romão, 2017, p. 52, tradução nossa) }\end{array}$ \\
\hline 27 & 0 & $\begin{array}{l}\text { "Nos últimos anos, o conceito de branding evoluiu para além do mundo corporativo e seu } \\
\text { significado como imagem ou reputação para incluir outros aspectos da mercantilização e } \\
\text { comodificação da vida cotidiana, como estratégia de diplomacia internacional e como forma }\end{array}$ \\
\hline
\end{tabular}




\begin{tabular}{|c|c|c|}
\hline $\mathbf{N}^{\mathbf{0}}$. & $\begin{array}{l}\text { Uso do } \\
\text { termo "soft } \\
\text { power" }\end{array}$ & Excertos textuais que se referem direta ou indiretamente à soft power \\
\hline & & $\begin{array}{l}\text { de expressão e organização sociopolítica (Aronczyk, 2013; Aronczyk \& Powers, 2010; } \\
\text { Arvidsson, 2006; Lury, 2004).” (Marsh, 2016, p. 3023) }\end{array}$ \\
\hline 28 & 0 & $\begin{array}{l}\text { "A criatividade é difícil; é difícil ser definida, ser medida, ser confiável para o } \\
\text { desenvolvimento econômico. Ainda assim, é extremamente poderosa para estimular } \\
\text { mudanças nas sociedades, organizações e mudar os rumos da gestão, sem falar nas mudanças } \\
\text { positivas que traz para os indivíduos. Ela influencia fortemente nossas próprias identidades, } \\
\text { bem como identidades de grupos menores ou maiores de sociedades que podem levar ao } \\
\text { desenvolvimento da cidade criativa." (Jelinčić \& Vukić, 2015, p. 8, tradução nossa). }\end{array}$ \\
\hline 29 & 0 & $\begin{array}{l}\text { "Valores asiáticos são incorporados à estratégia de economia criativa de Cingapura por meio } \\
\text { do cluster criativo que produz a marca New Asia como capital cultural hegemônico. [...] A } \\
\text { incorporação de valores asiáticos neste cluster para criar o capital cultural da "Nova Ásia" } \\
\text { atesta como a infraestrutura soft também é parte integrante da riqueza criativa de uma } \\
\text { economia." (Yue, } 2006, \text { p. } 22 \text {, tradução nossa) }\end{array}$ \\
\hline 30 & 0 & $\begin{array}{l}\text { "Desde a reunificação, Berlim passou a ser enaltecida tanto como uma cidade criativa e } \\
\text { cosmopolita (a "nova Berlim") quanto como um projeto social e cultural para demonstrar a } \\
\text { diversidade e a abertura da "nova Alemanha". Ela também ocupa um papel central no } \\
\text { imaginário da "nova Europa" e foi rotulada como o "epicentro europeu do jovem descolado"." } \\
\text { (Allon, 2013, pp. 291-292, tradução nossa) }\end{array}$ \\
\hline 31 & 0 & $\begin{array}{l}\text { "Além disso, a percepção positiva e a marca alcançável de uma cidade associada ao cinema } \\
\text { e à cultura podem tornar a cidade ainda mais atraente como um bom lugar para encontrar } \\
\text { novos investimentos econômicos (não necessariamente relacionados ao cinema)." (Cudny, } \\
2014, \text { p. } 40 \text {, tradução nossa) }\end{array}$ \\
\hline 32 & 0 & 3 \\
\hline 33 & 0 & $\begin{array}{l}\text { "Embalagens e marcas de bairros ou distritos podem assumir diferentes formas e atender a } \\
\text { vários objetivos. Claramente não é apenas uma ferramenta para atrair visitantes, pois pode } \\
\text { criar uma imagem comum e uma visão compartilhada para seus moradores (Ashworth \& } \\
\text { Kavaratzis 2010, Sneed et al. 2011)." (Karachalis \& Deffner, 2012, pp. 92-93, tradução } \\
\text { nossa). }\end{array}$ \\
\hline 34 & 0 & $\begin{array}{l}\text { "Nas sociedades pós-industriais, as indústrias criativas - juntamente com os serviços } \\
\text { financeiros e a economia do conhecimento - assumiram protagonismo nas políticas } \\
\text { governamentais a nível local e nacional e têm sido ostentadas como fontes de novas formas } \\
\text { de poder econômico e sustentabilidade em um mercado global cada vez mais competitivo." } \\
\text { (McElroy, 2011, p. 182, tradução nossa). }\end{array}$ \\
\hline 35 & 0 & $\begin{array}{l}\text { "Um produto manufaturado - um filme - deveria promover a imagem do Cazaquistão como } \\
\text { uma economia criativa e inovadora. Em outras palavras, a função do futuro filme era libertar } \\
\text { o país do anonimato, entregando uma 'mensagem [...] para o público mais amplo possível' } \\
\text { (Van Ham 2008: 129) e marcá-lo como um lugar atraente para investidores e turistas } \\
\text { internacionais." (Yessenova, 2011, p. 182, tradução nossa) }\end{array}$ \\
\hline 36 & 0 & $\begin{array}{l}\text { "É interessante saber se o elemento promocional do mix do marketing de lugares, } \\
\text { especialmente o desenvolvimento de marcas, pode ser efetivamente usado para aumentar os } \\
\text { fluxos de investimento (estrangeiro direto) das indústrias criativas. De acordo com Florida } \\
\text { (2002), lugares que construíram marcas fortes e dinâmicas têm uma tarefa mais fácil de atrair } \\
\text { empresas dentro das indústrias do conhecimento." (Jacobsen, 2010, p. 278). }\end{array}$ \\
\hline 37 & 0 & $\begin{array}{l}\text { "Embora outras cidades possam não experimentar a sorte inesperada de um filme de } \\
\text { Hollywood, o planejamento instigado em Wellington para se preparar para uma oportunidade } \\
\text { cultural popular é instrutivo. Ao alinhar as indústrias criativas, a cultura popular, e a teoria } \\
\text { da imagem da cidade, as GLAMs [Galerias, Bibliotecas, Arquivos e Museus] passam de uma } \\
\text { parte séria, mas discreta, do branding de lugar para um facilitador de mudanças econômicas } \\
\text { e sociais." (Brabazon, 2009, p. 260, tradução nossa). }\end{array}$ \\
\hline 38 & 0 & $\begin{array}{l}\text { "Como o foco da Flórida está na competição e no consumo de lugares, a cultura e as indústrias } \\
\text { criativas acabam sendo um espetáculo secundário instrumental que atrai trabalhadores } \\
\text { criativos, o que atrai investidores de alta tecnologia para as cidades (Peck, 2005; Pratt, } \\
\text { 2008)." (Liu \& Ko, 2010, p. 112, tradução nossa). }\end{array}$ \\
\hline 39 & 0 & - \\
\hline
\end{tabular}

Fonte: Elaborado pelos autores 


\section{Resultados e discussão}

$\mathrm{Na}$ Tabela 1, demonstramos que praticamente todos os artigos (38/39) apresentam valores positivos para a equação InOrdinatio (Fase 7), o que significa que devem ser considerados para análise posterior, conforme recomendado pelos autores do Methodi Ordinatio. Eles afirmam que "o número de artigos a serem lidos é decidido pelo pesquisador" (Pagani et al., 2015, p. 2121) - certamente considerando a diferença numérica de publicações em diferentes áreas do conhecimento.

Como nosso portfólio é relativamente pequeno, decidimos ler e revisar individualmente o conteúdo de todas as publicações, realizando a Fase 9 do Methodi Ordinatio.

Como visto na Tabela 2, o uso direto do termo soft power pôde ser encontrado em apenas 3 artigos (4, 7 e 23). Em outros quatro artigos (21-10-25-39), não foi encontrada nenhuma referência possível ao termo, direta ou indiretamente. Como mencionado anteriormente, isso é esperado e pode decorrer do fato de que o termo soft power retrata a imagem dos lugares em termos de política e relações internacionais, enquanto as variações de place branding referemse principalmente às dimensões mercadológicas e econômicas (Johnson, 2018).

Quase todos os estudos (34/36, com exceção dos artigos 32 e 39), contudo, de alguma forma fazem alusão ao conceito de soft power quando se referem à atratividade.

Na seção 2 (Referencial teórico), demonstramos que a ideia de atratividade parece ser o fator comum entre as ideias por trás de nation branding e de soft power. Joseph Nye escreveu recentemente que o soft power funciona "como um ímã" (2021, p. 201, tradução nossa) e, no passado, Anholt substituiu o termo marca nacional por identidade nacional como uma reafirmação, considerando que branding "é uma frase perigosamente enganosa que parece conter uma promessa de que as imagens dos países podem ser manipuladas diretamente usando as técnicas de comunicação de marketing comercial” (Anholt, 2013, p. 1) e, portanto, a identidade de um país deve ser desenvolvida "para ganhar uma reputação que seja justa; verdadeira; poderosa; atraente; genuinamente útil para seus objetivos econômicos, políticos e sociais". (Anholt, 2013, p. 9, tradução nossa).

Desse ponto de vista, o que nossa pesquisa acaba por demonstrar é que os autores sobre place branding podem não ter usado o termo soft power em si, mas aludem obliquamente ao seu conceito quando olham para os lugares como um objeto que fomenta a atratividade por meio de elementos "soft", como visto nos trechos textuais na Tabela 2. 
Por exemplo, quando Warren \& Dinnie (2018, p. 304) - artigo 13 - dizem que os profissionais de marketing de lugar "criam identidades específicas que representam certas formas de ver a realidade e têm um certo grau de poder sobre como a realidade é percebida pelo público-alvo", entendemos que são alusões ao soft power e à psicossociologia. Ou quando Farhat (2019, p. 12) - artigo 15 - afirma que "as estratégias suaves tornaram-se centrais para criar comunidades culturais e estimular a atividade econômica", postulamos que se trata de uma sutil alusão ao soft power, e estudos futuros poderiam investigar sua relação com o planejamento urbano.

A partir dessa abordagem oblíqua, inferimos cinco caminhos inexplorados (ou pouco explorados) que relacionam poder, lugares e a atratividade da criatividade: psicossociologia, mobilidade laboral, planejamento urbano, diplomacia artística, gastrodiplomacia, e indicações geográficas.

Vale ressaltar que as inferências não são raras na prática científica e são utilizadas quando o interesse não está na descrição dos conteúdos, mas na construção do conhecimento relativo (Bardin, 2011).

Oportunamente, também é importante destacar que o objetivo deste artigo é "apresentar diretrizes interdisciplinares de pesquisas futuras sobre soft power". Portanto, utilizando a metodologia proposta, nossos resultados consistem fundamentalmente em interpretações de sutis alusões ao soft power e inferências sobre sua relação com outros campos do conhecimento.

Testamos nossos resultados verificando se as diretrizes inferidas já foram abordadas e ignoradas. Conforme observado no mapa do VOSviewer (Figura 3), [“soft power"] não é uma palavra-chave central. Assim, na Figura 4 a seguir, a utilizamos como tal e realizamos uma busca simples na base Scopus, onde é ilustrada a virtual ausência de estudos nessas áreas.

Na Tabela 3, descrevemos sucintamente cada área das diretrizes propostas, relacionando-as com os trabalhos resultantes do Methodi Ordinatio e suas referências oblíquas - previamente confirmadas pela análise de conteúdo, na Tabela 2. 


\section{Figure 4}

\section{Conjunto de Diretrizes de Pesquisa Futura Sobre Soft Power e Visão Geral do Scopus}

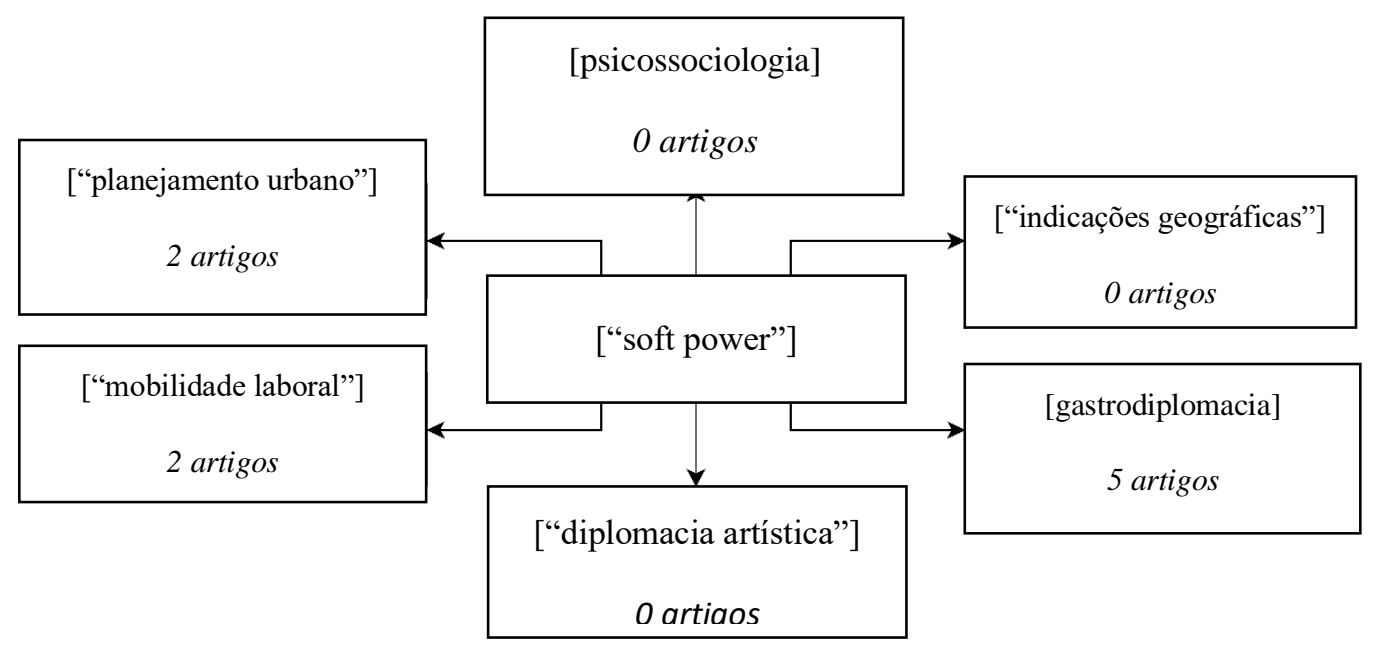

Fonte: Elaborado pelos autores.

\section{Tabela 3}

\section{Diretrizes Para Pesquisas Futuras e Suas Referências Oblíquas}

\begin{tabular}{|c|c|c|}
\hline Área do conhecimento & Breve descrição & Referências oblíquas \\
\hline Psicossociologia & $\begin{array}{l}\text { Estuda as maneiras pelas quais a } \\
\text { experiência subjetiva está entrelaçada com } \\
\text { a vida social. Abrange uma ampla gama de } \\
\text { assuntos, incluindo política, nações e } \\
\text { estados, comunidades e vida coletiva. } \\
\text { (APS, 2021). }\end{array}$ & $\begin{array}{l}\text { Jones (2009); Moreno (2020); } \\
\text { Warren \& Dinnie (2018); Listerborn } \\
\text { (2017); Scott \& Szili (2018); Marsh } \\
\text { (2016); Jelinčić \& Vukić (2015); Yue } \\
\text { (2006); Allon (2013); Karachalis \& } \\
\text { Deffner (2012) }\end{array}$ \\
\hline Mobilidade laboral & $\begin{array}{l}\text { Para Chow (2017), a dinâmica da } \\
\text { mobilidade dos trabalhadores é largamente } \\
\text { configurada tanto pelas preocupações com } \\
\text { as situações de emprego quanto pela } \\
\text { atratividade do lugar. Os lugares devem } \\
\text { tentar o seu melhor para atrair e reter } \\
\text { trabalhadores talentosos. }\end{array}$ & $\begin{array}{l}\text { Scott (2004); Currid \& Williams } \\
\text { (2010); Lee et al. (2015); Askegaard } \\
\text { \& Kjeldgaard (2007); Dudek- } \\
\text { Mańkowska \& Grochowski (2019); } \\
\text { Scott \& Szili (2018); Chow (2017); } \\
\text { Romão (2017); Jacobsen (2010); Liu } \\
\text { \& Ko (2010) }\end{array}$ \\
\hline Planejamento urbano & $\begin{array}{l}\text { A ligação entre place branding e } \\
\text { planejamento urbano foi recentemente } \\
\text { estudada por Bonakdar \& Audirac (2020). } \\
\text { Para eles, a participação pública é } \\
\text { fundamental nas políticas de planejamento } \\
\text { urbano para gerar, legitimar e autenticar a } \\
\text { criação de imaginários urbanos. }\end{array}$ & $\begin{array}{l}\text { Lange et al. (2008); Hristova (2019); } \\
\text { Farhat (2019); Listerborn (2017); } \\
\text { Maheshwari et al. (2019); Allon } \\
\text { (2013); Karachalis \& Deffner (2012) }\end{array}$ \\
\hline Diplomacia artística & $\begin{array}{l}\text { "A diplomacia das artes é uma resposta } \\
\text { aos desejos dos públicos estrangeiros" } \\
\text { (Brown, 2020, p. 81, tradução nossa). Pode } \\
\text { ser definida como o uso da arte como } \\
\text { instrumento de criação de impressões } \\
\text { poderosas em públicos de diferentes } \\
\text { lugares do mundo. }\end{array}$ & $\begin{array}{l}\text { Lee et al. (2015); Valaskivi (2013); } \\
\text { Cudny et al. (2020); Oh (2020); } \\
\text { Loftsdóttir et al. (2017); Navarro } \\
\text { (2016); Brabazon (2009) }\end{array}$ \\
\hline
\end{tabular}




\begin{tabular}{|c|c|c|}
\hline Área do conhecimento & Breve descrição & Referências oblíquas \\
\hline Gastrodiplomacia & $\begin{array}{l}\text { É um termo que existe no âmbito da } \\
\text { diplomacia cultural. Refere-se a como a } \\
\text { comida pode aumentar a conscientização } \\
\text { sobre a distinção da cultura única de uma } \\
\text { nação. (Rockower, 2012) }\end{array}$ & Askegaard \& Kjeldgaard (2007); \\
\hline $\begin{array}{l}\text { Geographical } \\
\text { Indications }\end{array}$ & $\begin{array}{l}\text { Lee et al. referem-se ao terroir, uma } \\
\text { terminologia francesa familiar sobre o } \\
\text { tema das Indicações Geográficas. Para } \\
\text { Herman (2009, p. 48), terroir, "no fundo, } \\
\text { trata-se de memórias e narrativas } \\
\text { poderosas que, compartilhadas, nos } \\
\text { possibilitam consumir os sabores e } \\
\text { prazeres de um lugar". }\end{array}$ & Lee et al. (2015) \\
\hline
\end{tabular}

Fonte: Elaborado pelos autores.

\section{Conclusões e agenda de pesquisas futuras}

Neste artigo, apresentamos uma revisão sistemática da literatura, composta por uma análise de conteúdo com abordagem oblíqua, sobre a correlação entre place branding, indústria criativa e soft power da maior base de resumos e citações da literatura revisada por pares, a Scopus. Esta revisão é bastante extensa e explora publicações genuinamente relevantes sobre os temas, conforme demonstrado pela equação InOrdinatio, do Methodi Ordinatio.

O objetivo principal do nosso trabalho foi construir uma agenda interdisciplinar para pesquisas futuras. Quando se trata de soft power, place branding e indústrias criativas, parece que essa interdisciplinaridade pode se estender a outros campos do conhecimento.

Neste artigo, apresentamos seis, e eles foram obtidos por meio da interpretação de alusões sutis na literatura revisada. Nesta seção, também apresentamos duas áreas potenciais para investigação adicional, inferidas a partir de observações indiretas.

No tema Psicossociologia, entendemos que um tema interessante para futuras pesquisas é o imaginário social e a memória coletiva dos lugares e como eles refletem o poder suave do lugar. Considerando que branding envolve ficcionalização, criação de mitos e criação de associações afetivas lucrativas com produtos, lugares ou pessoas (Marsh, 2016), a imaginação e a memória podem ser uma fonte particular (e coletiva) de soft power.

Quanto à Mobilidade Laboral e Planejamento Urbano, podemos inferir que as cidades criativas detêm soft power sobre as demais em termos de atração e retenção de talentos, e estudos futuros poderão explorar o que trabalhadores altamente qualificados esperam a partir de então, no contexto atual de trabalho remoto. 
A Diplomacia Artística e a Gastrodiplomacia estão dentro do que já é conhecido como diplomacia cultural. São termos relativamente novos, e pesquisas futuras sobre soft power podem explorar como artes e comidas mundialmente conhecidas podem ser atraentes para alguns países, mas não para outros, considerando que proporcionam experiências e memórias altamente subjetivas.

Decisivamente, as Indicações Geográficas podem ser um tópico interessante para investigação em termos de place branding e soft power. São instrumentos coletivos intransferíveis que podem conectar pessoas e produtos com seu patrimônio cultural e histórico (Bowen \& Zapata, 2009), atraindo pessoas de diferentes lugares para viver parte de seu próprio modus vivendi. Aqui, pesquisas futuras podem abordar como o consumo de produtos de regiões certificadas pode moldar os hábitos e comportamentos das pessoas em relação aos lugares.

Como mencionado anteriormente, nossas observações nos permitem inferir dois caminhos adicionais para pesquisas futuras.

Decidimos chamar a primeira de "interpretações equivocadas de place branding". Para diferentes pessoas de diferentes partes do mundo, é possível que os símbolos impressos em marcas e lugares possam estar relacionados a outros países que não o "detentor" original dessa imagem. Em alguns lugares, o glamour da marca Gucci, por exemplo, pode estar mais associado na mente das pessoas aos Estados Unidos, celebridades hollywoodianas e músicos ostensivos do que à sofisticação da moda italiana.

Também poderia valer a pena estudar a "dinâmica de acesso à imagem do lugar por meio de produtos criativos e tradicionais", esclarecendo como eles aumentam ou diminuem soft power. Produtos falsificados são um bom exemplo aqui: imitações estão presentes principalmente em economias emergentes e tentam (ou inadvertidamente conseguem) imprimir a imagem de um país estrangeiro. No Brasil, por exemplo, pode-se dizer que as pessoas estão conhecendo novos lugares e culturas em todo o mundo quando têm acesso à produtos como as camisas de futebol da Europa e as roupas de basquete dos Estados Unidos, com seus times com nomes de cidades (Barcelona, Manchester City, Paris Saint-Germain, Los Angeles Lakers, Boston Celtics, e assim por diante). Enquanto estes produtos (embora de baixa qualidade) possam estimular associações positivas com esses lugares, o contrário pode acontecer com produtos de qualidade inferior e falsificados que não possuem marca, onde os brasileiros podem prontamente associá-los à China. Aparelhos e objetos tecnológicos de baixa qualidade, por exemplo, podem desencadear imagens negativas do país asiático. 
Nossa principal conclusão é que, embora o ramo de conhecimento do soft power tenha sido predominantemente olhado com foco na perspectiva política dos países, também é um pensamento relativamente novo que permeia as mentes dos estudiosos da pesquisa de marketing. Soft power deve então ser visto como um assunto interdisciplinar, e há várias questões de pesquisa interessantes que podem ser derivadas deste estudo.

Para encerrar, é importante destacar que este artigo, de fato, apresenta desafios teóricos para acadêmicos, mas também apresenta áreas pouco exploradas por profissionais e formuladores de políticas, que poderiam aproveitá-lo para o planejamento da imagem de cidades, regiões e países. Do nosso ponto de vista, as áreas que envolvem artes e gastronomia parecem ser iniciativas viáveis para o curto prazo, enquanto ações praticáveis em psicossociologia, mobilidade laboral, planejamento urbano e indicações geográficas podem ser mais demoradas e custosas.

\section{Limitações}

Uma das principais limitações deste estudo é que ele utiliza apenas uma base de dados científica. Além disso, a abordagem oblíqua para revisão de literatura ainda não foi perfeitamente descrita como um método científico, e a análise de conteúdo pode estar sujeita a suposições e vieses.

Além disso, apesar do Methodi Ordinatio ser um método robusto para encontrar publicações científicas de alta relevância, é impraticável para livros, capítulos de livros ou trabalhos apresentados em congressos científicos e, por isso, estes tipos de material não foram analisados neste estudo, embora possam conter outros e interessantes caminhos para uma agenda de pesquisa.

Isso quer dizer que pesquisas futuras poderiam, de fato, explorar de forma frutífera os novos caminhos que este estudo revelou. Mas pesquisadores - e profissionais - devem sempre ter em mente que soft power, indústrias criativas e place branding são objetos de estudo interdisciplinares, e que há muito mais deste mundo desconhecido para explorar. Assim como Alexander von Humboldt já o fez. 


\section{Agradecimentos}

Agradecemos seriamente o apoio financeiro da Coordenação de Aperfeiçoamento de Pessoal de Nível Superior (CAPES), no Brasil.

\section{Referências}

Allon, F. (2013). Ghosts of the open city. Space and Culture, 16(3), 288-305.

https://doi.org/10.1177/1206331213487054

Anholt, S. (2005). Brand New Justice: How Branding Places and Products Can Help the Developing World. 173.

Anholt, S. (2010). Places: Identity, Image and Reputation (1st ed.). Palgrave Macmillan.

Anholt, S. (2013). Beyond Nation Brand: The Role of Image and Identity in International Relations. Exchange: The Journal of Public Diplomacy, 2(1).

s://surface.syr.edu/exchange/vol2/iss 1/1

APS - The Association for Psychosocial Studies. (2021). What is Psychosocial Studies? http://www.psychosocial-studies-association.org/about/

Askegaard, S., \& Kjeldgaard, D. (2007). Here, there, and everywhere: Place branding and gastronomical globalization in a macromarketing perspective. Journal of Macromarketing, 27(2), 138-147. https://doi.org/10.1177/0276146707300068

Bardin, L. (2011). Análise de Conteúdo. Edições 70.

Bauer, M. W. (2000). Classical Content Analysis: a Review. In M. W. Bauer \& G. Gaskell (Eds.), Qualitative Researching with Text, Image and Sound (p. 374). SAGE Publications.

Bell, F. (2016). Looking beyond place branding: the emergence of place reputation. Journal of Place Management and Development, 9(3), 247-254.

Boisen, M., Terlouw, K., Groote, P., \& Couwenberg, O. (2017). Reframing place promotion, place marketing, and place branding - moving beyond conceptual confusion. Cities, 80(January), 4-11. https://doi.org/10.1016/j.cities.2017.08.021

Bonakdar, A., \& Audirac, I. (2020). City Branding and the Link to Urban Planning: Theories, Practices, and Challenges. Journal of Planning Literature, 35(2), 147-160. https://doi.org/10.1177/0885412219878879

Bowen, S., \& Zapata, A. V. (2009). Geographical indications, terroir, and socioeconomic and ecological sustainability: The case of tequila. Journal of Rural Studies, 25(1), 108-119. https://doi.org/https://doi.org/10.1016/j.jrurstud.2008.07.003 
Brabazon, T. (2009). Brand Wellington: When city imaging is GLAMed: A personal view. Place Branding and Public Diplomacy, 5(4), 260-275. https://doi.org/10.1057/pb.2009.22 Braun, V., \& Clarke, V. (2012). Thematic Analysis. In H. M. Cooper \& P. M. Camic (Eds.), APA Handbook of Research Methods in Psychology. American Psychological Association.

Brown, J. (2020). Arts Diplomacy: The Neglected Aspect of Cultural Diplomacy. In N. Snow \& N. J. Cull (Eds.), Routledge Handbook of Public Diplomacy. Routledge.

Cambridge Dicionary. (2018). https://dictionary.cambridge.org/dictionary/germanenglish/fernweh

Chow, Y. F. (2017). Exploring creative class mobility: Hong Kong creative workers in Shanghai and Beijing. Eurasian Geography and Economics, 58(4), 361-385. https://doi.org/10.1080/15387216.2017.1365311

Cudny, W. (2014). Vliv televizního seriálu "Komisař Alex" na rozvoj Lodže (Polsko) očima jeho obyvatel. Moravian Geographical Reports, 22(1), 33-43. https://doi.org/10.2478/mgr2014-0004

Cudny, W., Comunian, R., \& Wolaniuk, A. (2020). Arts and creativity: A business and branding strategy for Lodz as a neoliberal city. Cities, 100. https://doi.org/10.1016/j.cities.2020.102659

Currid, E., \& Williams, S. (2010). The geography of buzz: Art, culture and the social milieu in Los Angeles and New York. Journal of Economic Geography, 10(3), 423-451. https://doi.org/10.1093/jeg/lbp032

Dudek-Mańkowska, S., \& Grochowski, M. (2019). From creative industries to the creative place brand: some reflections on city branding in Poland. Place Branding and Public Diplomacy, 15(4), 274-287. https://doi.org/10.1057/s41254-019-00141-7

Fan, Y. (2010). Branding the nation: Towards a better understanding. Place Branding and Public Diplomacy, 6(2), 97-103. https://doi.org/10.1057/pb.2010.16

Farhat, R. R. (2019). What Brand Is This Place? Place-Making and the Cultural Politics of Downtown Revitalization. Space and Culture, 22(1), 34-49. https://doi.org/10.1177/1206331217751778

Florek, M., Hereźniak, M., \& Augustyn, A. (2021). Measuring the effectiveness of city brand strategy. In search for a universal evaluative framework. Cities, 110(December 2020). https://doi.org/10.1016/j.cities.2020.103079

Fung, A. (2016). Strategizing for creative industries in China: Contradictions and tension in nation branding. International Journal of Communication, 10, 3004-3021.

Galeeva, D. (2020). Putting tatars on the map: The place branding versus soft power of Tatarstan. Place Branding and Public Diplomacy. https://doi.org/10.1057/s41254-020-001690

Hankinson, G. (2010). Place branding research: A cross-disciplinary agenda and the views of practitioners. Place Branding and Public Diplomacy, 6(4), 300-315. https://doi.org/10.1057/pb.2010.29 
Hao, A. W., Paul, J., Trott, S., Guo, C., \& Wu, H. H. (2019). Two decades of research on nation branding: a review and future research agenda. International Marketing Review, 38(1), 46-69. https://doi.org/10.1108/IMR-01-2019-0028

Herman, B. L. (2009). Drum Head Stew: The Power and Poetry of Terroir. Southern Cultures, 15(4), 36-49.

Hristova, A. (2019). Architecture as a cultural sustainability factor of Macedonian cities: The branding of Bitola. Sustainable Development, 27(2), 227-236. https://doi.org/10.1002/sd.1881

Hsieh, H. F., \& Shannon, S. E. (2005). Three approaches to qualitative content analysis. Qualitative Health Research, 15(9), 1277-1288. https://doi.org/10.1177/1049732305276687

Jacobsen, B. P. (2010). Urban place brands and the location of creative industries: A model for measuring place-brand equity. Urban Research and Practice, 3(3), 275-298. https://doi.org/m

Jelinčić, D. A., \& Vukić, F. (2015). Le industrie creative come artefici dell'identità urbana e motori dello sviluppo: Dal branding direzionale a quello partecipativo. Annales-Anali Za Istrske in Mediteranske Studije - Series Historia et Sociologia, 25(3), 527-536.

Johnson, M. A. M. A. (2018). Culture as soft power: Digital branding by catalonia, the basque country and Scotland. Catalan Journal of Communication and Cultural Studies, 10(1), 115124. https://doi.org/10.1386/cjcs.10.1.115_1

Jones, P. (2009). Putting architecture in its social place: A cultural political economy of architecture. Urban Studies, 46(12), 2519-2536. https://doi.org/10.1177/0042098009344230

Kahraman, E. (2016). A Methodological Approach to Nation Branding. In N. Chitty, L. Ji, G. Rawnsley, \& C. Hayden (Eds.), The Routledge Handbook of Soft Power (1st ed., pp. 93-103). Routledge.

Karachalis, N., \& Deffner, A. (2012). Rethinking the connection between creative clusters and city branding: The cultural axis of piraeus street in athens. Quaestiones Geographicae, 31(4), 87-97. https://doi.org/10.2478/v10117-012-0038-0

Kay, J. (2011). Obliquity: Why our goals are best achieved indirectly. The Penguin Press.

Lange, B., Kalandides, A., Stöber, B., \& Mieg, H. A. (2008). Berlin's creative industries: Governing creativity? Industry and Innovation, 15(5), 531-548. https://doi.org/10.1080/13662710802373981

Lee, A. H. J., Wall, G., \& Kovacs, J. F. (2015). Creative food clusters and rural development through place branding: Culinary tourism initiatives in Stratford and Muskoka, Ontario, Canada. Journal of Rural Studies, 39, 133-144. https://doi.org/10.1016/j.jrurstud.2015.05.001

Lee, S. T. (2021). Film as cultural diplomacy: South Korea's nation branding through Parasite (2019). Place Branding and Public Diplomacy. https://doi.org/10.1057/s41254-020-00192-1 
Listerborn, C. (2017). The flagship concept of the '4th urban environment'. Branding and visioning in Malmö, Sweden. Planning Theory and Practice, 18(1), 11-33. https://doi.org/10.1080/14649357.2016.1264615

Liu, L. W., \& Ko, P. Y. (2010). A local city to a creative city: An examination of Taichung, Taiwan. International Journal of Sustainable Development, 13(1-2), 111-121. https://doi.org/10.1504/IJSD.2010.035103

Loftsdóttir, K., Kjartansdóttir, K., \& Lund, K. A. (2017). Trapped in clichés: masculinity, films and tourism in Iceland. Gender, Place and Culture, 24(9), 1225-1242. https://doi.org/10.1080/0966369X.2017.1372383

Lucarelli, A., \& Berg, P. O. (2011). City branding: A state-of-the-art review of the research domain. Journal of Place Management and Development, 4(1), 9-27.

https://doi.org/10.1108/17538331111117133

Lucarelli, A., \& Giovanardi, M. (2016). The political nature of brand governance: A discourse analysis approach to a regional brand building process. Journal of Public Affairs, 16(1), 1627. https://doi.org/10.1002/pa.1557

Maheshwari, V., Giraldi, J. de M. E., \& Montanari, M. G. (2019). Investigating residents' attitudes of 2016 Olympic Games: Examining socio-cultural, economic and environmental dimensions. Journal of Place Management and Development, 12(3), 291-313. https://doi.org/10.1108/JPMD-08-2018-0059

Marc, I. (2019). Around the world: France's new popular music diplomacy. Modern and Contemporary France, 28(3), 253-270. https://doi.org/10.1080/09639489.2019.1682533

Mariutti, F. G., \& Giraldi, J. de M. E. (2021). Branding cities, regions and countries: the roadmap of place brand equity. RAUSP Management Journal, 56(2), 202-216. https://doi.org/10.1108/rausp-06-2020-0131

Mariutti, F. G., \& Tench, R. (2016). How does Brazil measure up? Comparing rankings through the lenses of nation brand indexes. Place Branding and Public Diplomacy, 12(1), 17-31. https://doi.org/10.1057/pb.2015.19

Marsh, L. L. (2016). Branding Brazil through cultural policy: Rio de Janeiro as a creative, audiovisual city. International Journal of Communication, 10, 3022-3041.

Mattern, J. B. (2005). Why "Soft Power" isn't so soft: Representational force and attraction in world politics. Millennium: Journal of International Studies, 33(3), 583-612. https://doi.org/10.1177/03058298050330031601

McElroy, R. (2011). Putting the landmark back into television: Producing place and cultural value in Cardiff. Place Branding and Public Diplomacy, 7(3), 175-184. https://doi.org/10.1057/pb.2011.20 
Navarro, B. (2016). Creative industries and Britpop: the marketisation of culture, politics and national identity. Consumption Markets and Culture, 19(2), 228-243. https://doi.org/10.1080/10253866.2015.1068168

Nye, J. S. (1990). Bound to lead: the changing nature of American power. Basic Books.

Nye, J. S. (2004). Soft Power: The means to success in world politics (1st ed.). PublicAffairs.

Nye, J. S. (2021). Soft power: the evolution of a concept. Journal of Political Power, 14(1), 196-208. https://doi.org/10.1080/2158379X.2021.1879572

Oh, Y. (2020). From concrete walls to digital walls: transmedia construction of place myth in Ihwa Mural Village, South Korea. Media, Culture and Society, 42(7-8), 1326-1342. https://doi.org/10.1177/0163443720916410

Pagani, R. N., Kovaleski, J. L., \& Resende, L. M. (2015). Methodi Ordinatio: a proposed methodology to select and rank relevant scientific papers encompassing the impact factor, number of citation, and year of publication. Scientometrics, 105(3), 2109-2135. https://doi.org/10.1007/s11192-015-1744-X

Pedeliento, G., \& Kavaratzis, M. (2019). Bridging the gap between culture, identity and image: a structurationist conceptualization of place brands and place branding. Journal of Product and Brand Management, 28(3), 348-363. https://doi.org/10.1108/JPBM-01-2018-1735

Rabêlo Neto, A., Sousa-Filho, J. M. de, \& Carneiro Lima, A. (2021). Internationalization of culture and soft power. European Business Review. https://doi.org/10.1108/EBR-09-20190240

Rius Ulldemolins, J., \& Zamorano, M. M. (2015). Spain's nation branding project Marca España and its cultural policy: the economic and political instrumentalization of a homogeneous and simplified cultural image. International Journal of Cultural Policy, 21(1), 20-40. https://doi.org/10.1080/10286632.2013.877456

Rivero Moreno, L. D. L. D. (2020). Sustainable city storytelling: cultural heritage as a resource for a greener and fairer urban development. Journal of Cultural Heritage Management and Sustainable Development. https://doi.org/10.1108/JCHMSD-05-2019-0043

Rockower, P. S. (2012). Recipes for gastrodiplomacy. Place Branding and Public Diplomacy, 8(3), 235-246. https://doi.org/10.1057/pb.2012.17

Romão, J. (2017). Are creative cities good places for creative people? Notes on the social conditions for cultural production in contemporary economy. Quality Innovation Prosperity, 21(1), 49-60. https://doi.org/10.12776/QIP.V21I1.777

Rookwood, J. (2019). Access, security and diplomacy: Perceptions of soft power, nation branding and the organisational challenges facing Qatar's 2022 FIFA World Cup. Sport, Business and Management: An International Journal, 9(1), 26-44.

https://doi.org/10.1108/SBM-02-2018-0016 
Scott, A. (2004). Cultural-products industries and urban economic development: Prospects for growth and market contestation in global context. Urban Affairs Review, 39(4), 461-490. https://doi.org/10.1177/1078087403261256

Scott, M., \& Szili, G. (2018). Pop-up Polanyi: Cultural entrepreneurs and the 'vacancy fix.' City, Culture and Society, 14, 22-27. https://doi.org/10.1016/j.ccs.2017.12.005

Skinner, H. (2008). The emergence and development of place marketing's confused identity. Journal of Marketing Management, 24(9-10), 915-928.

https://doi.org/10.1362/026725708X381966

Valaskivi, K. (2013). A brand new future? Cool Japan and the social imaginary of the branded nation. Japan Forum, 25(4), 485-504. https://doi.org/10.1080/09555803.2012.756538

Van Eck, N. J., \& Waltman, L. (2010). Software survey: VOSviewer, a computer program for bibliometric mapping. Scientometrics, 84(2), 523-538. https://doi.org/10.1007/s11192-0090146-3

Wang, J. (2013). Shaping China's Global Imagination: Branding Nations at the World Expo. In J. Wang (Ed.), Shaping China's Global Imagination: Public Diplomacy through Communication. Palgrave Macmillan.

Warren, G., \& Dinnie, K. (2018). Cultural intermediaries in place branding: Who are they and how do they construct legitimacy for their work and for themselves? Tourism Management, 66, 302-314. https://doi.org/10.1016/j.tourman.2017.12.012

Wulf, A. (2015). The Invention of Nature: Alexander Von Humboldt's New World - Andrea Wulf - Google Books. Alfred A. Knopf.

Yessenova, S. (2011). Nomad for export, not for domestic consumption: Kazakhstan's arrested endeavour to 'put the country on the map.' Studies in Russian and Soviet Cinema, 5(2), 181203. https://doi.org/10.1386/srsc.5.2.181_1

Yue, A. (2006). Cultural governance and creative industries in Singapore. International Journal of Cultural Policy, 12(1), 17-33. https://doi.org/10.1080/10286630600613176 